\title{
Lista dwunastu plemion w Ap 7,5-8
}

\section{The List of the Twelve Tribes in Rev 7:5-8}

Słowa klucze: Księga Apokalipsy, 144000 opieczętowanych, dwanaście plemion Izraela, Manasses, Efraim, Dan.

Key words: The Book of Revelation, 144000 sealed, twelve tribes of Israel, Manasseh, Ephraim, Dan.

$\mathrm{P}$ odczas gdy ST podaje niemal trzydzieści, mniej lub bardziej kompletnych, list dwunastu synów Jakuba/Izraela, czy też plemion Izraela ${ }^{1}$, NT prezentuje tylko jedną, znajdującą się w Ap 7,5-8. Zdumiewające, iż ta jedyna nowotestamentowa lista nie znajduje swego odpowiednika w żadnej z list starotestamentowych zarówno pod względem kolejności wymienianych plemion, jak i doboru imion epigonów poszczególnych plemion. Okazuje się także, że

1 Z. Kallai („The Twelve-Tribe Systems of Israel”, VT 47 [1997] 53-90) wyróżnia cztery schematy list starotestamentowych, dwa bazujące na kluczu genealogicznym (I, II) i dwa idące za kluczem geograficznym (III, IV). Występujące odstępstwa od powyższych schematów są jednostkowe, dlatego nie można mówić o istnieniu innych schematów. Schemat I: Listy genealogiczne bazujące na sekwencji narodzin z poszczególnych matek (Lea, Rachela, Zilpa, Bilha). Kolejność, w jakiej występują dzieci żon Jakuba (Lea, Rachela) i niewolnic jego żon (Zilpa i Bilha), jest dowolna. Zob. Rdz 29,32-30,24 razem z Rdz 35,17-18; następnie Rdz 33,1-2; 35,23-26; 46,8-25; 49,3-27; Wj 1,2-4; 6,13-26; Lb 13,4-15; Pwt 27,12-13; 33,6-25; Ezk 48,31-34; 1 Krn $2,1-2 ; 2-9 ; 27,16-22$. Schemat II: Listy genealogiczne związane $\mathrm{z}$ rozmieszczeniem terytorialnym pokoleń. W listach tych brakuje pokolenia Lewiego oraz Józefa, obecni są natomiast dwaj synowie Józefa. Kolejność, w jakiej występują plemiona, eksponuje znaczenie Judy. Zob. Lb 1,5-16; 1,20-46; 2,3-31; 7,12-73; 10,14-27; 26,5-50. Schemat III: Listy bazujące na podziale terytorialnym z pokoleniem Dana na południu. Zob. Lb 34,19-28; Joz 21,4-7.9-38; 1 Krn 6,39-48; 6,50-66. Schemat IV: Listy odzwierciedlające ostateczny podział terytorium z pokoleniem Dana na północy. Zob. Joz 13-19; Sdz 1,2-35; 5,14-18; 48,1-28; 1 Krn 12,25-38. 
listy obecne w żydowskiej literaturze pozabiblijnej również nie znają takiej sekwencji imion ${ }^{2}$. Poniższe studium listy plemion w Ap 7,5-8 ma za cel prezentację najbardziej prawdopodobnych wyjaśnień dwóch powyższych trudności, a mianowicie (1) unikalnej kolejności, w jakiej wymienione są plemiona oraz (2) niemającego precedensu doboru tychże plemion, w którym to pomija się plemiona Dana i Efraima, a wzmiankuje się plemiona Józefa i Manassesa. Jako że rozwiązanie dwóch powyższych trudności związane jest pośrednio z identyfikacją 144000 opieczętowanych w Ap 7,4, zasadnicza część naszej analizy poprzedzona zostanie krótkim przeglądem propozycji współczesnych komentatorów dotyczących tożsamości opieczętowanych wraz ze wskazaniem preferowanego przez nas wyjaśnienia.

\section{Tożsamość 144000 opieczętowanych}

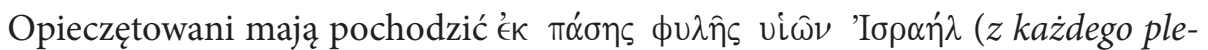

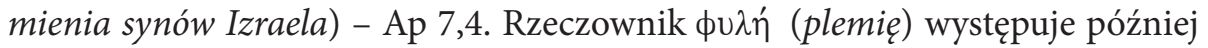

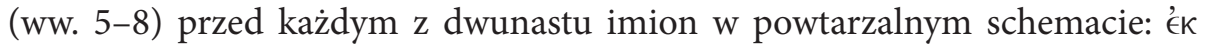

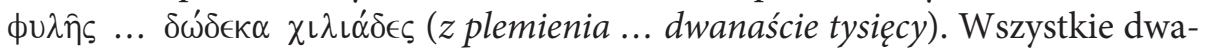
naście imion, które występują w ww. 5-8, to imiona starotestamentowych epigonów, którzy dali początek dwunastu szczepom starożytnych Izraelitów.

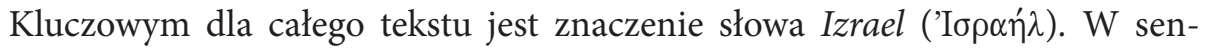
sie dosłownym odnosi się ono do Hebrajczyków, czy też Izraelitów. Wówczas 144000 opieczętowanych stanowiłoby wybraną grupę Żydów, dla przykładu: (1) świętych okresu $\mathrm{ST}^{3}$ lub też (2) Żydów, którzy przyjęli chrześcijaństwo ${ }^{4}$. Istnieje także możliwość odniesienia słowa Izrael do wspólnoty chrześcijańskiej. Nowy Testament dostarcza przykładów, gdzie chrześcijanie, czy też Kościót określani są jako prawdziwy Izrael (Ga 6,16; 1 P 2,9) lub dwanaście plemion $(J \mathrm{k} 1,1)^{5}$. Przyjmując takie znaczenie terminu Izrael, opieczętowani mogą być

2 Zob. Józef Flawiusz, Ant. 2, 177-183; Pseudo-Filon, LAB 8,6; 8,11-14; 10,3; 25,4; 25,9-13; 26,10-11; Księga Jubileuszy 33,22; 44,11-34; Zwój Świątyni (11Q19) XXIV 11-16; XXXIX 11-XL[1ss]; XL 14-XLI 11; XLIV-XLV; Testamenty Dwunastu Patriarchów. Istnieją także dwie niepełne listy w opisie bram Nowej Jerozolimy w 4Q365a (tylko ostatnich pięć imion) oraz 4Q554 (zachowało się tylko pięć imion, z których tylko dwa następują po sobie).

3 E. Corsini, The Apocalypse. The Perennial Revelation of Jesus Christ (Good News Studies 5; Wilmington: Glazier 1983) 158-159.

4 A. Feuillet, Les 144.000 Israélites marqués d’un sceau, NT 9 (1967) 191-224.

5 Fakt przyjęcia takiego nazewnictwa przez chrześcijan, a więc zbiorowość mniejszą niż etniczny Izrael dwunastu plemion, ma swoje paralele zarówno w ST, jak i w zwojach 
widziani jako część wspólnoty chrześcijańskiej (bez względu na ich żydowskie, czy też pogańskie pochodzenie), dla przykładu: (3) chrześcijańscy męczenni$\mathrm{cy}^{6}$ albo też (4) charakterystyczna dla czasów ostatecznych grupa specjalnie zachowanych od plag i prześladowań chrześcijan ${ }^{7}$, lub (5) chrześcijańska armia powołana do walki w eschatologicznej wojnie mesjańskiej ${ }^{8}$. W powyższych przykładach widać, że komentatorzy bardzo dosłownie rozumieją użycie liczb 144 000, 12000 oraz przyimka ék. Przyimek '́k miałby wskazywać, że liczba opieczętowanych rekrutuje się spośród Izraela, a zatem jest jedynie częścią tegoż Izraela. Jeśli rozumieć liczby 144000 oraz 12000 na sposób symboliczny w ślad za symbolicznym znaczeniem innych liczb w Ap - odnosiłyby się one do rzeszy opieczętowanych tworzących Izrael zbudowany z dwunastu plemion,

qumrańskich. W świetle Ezd 6,16-17 widać, że mimo, iż powracający z wygnania babilońskiego pochodzili jedynie z trzech plemion (Juda, Beniamin i Lewi - zob. Ezd 1,5), ta garstka ocalonych (Ezd 9,8) uważała siebie za reprezentantów dwunastu pokoleń Izraela. Także wspólnota qumrańska utożsamiała siebie z prawdziwym Izraelem (zob. przypis 64) oraz dwunastoma plemionami Izraela (zob. 4Q164; 11Q19 LVII 11-15). Dla przykładu, dwunastu świeckich mężów, reprezentantów dwunastu plemion, wraz z trzema kapłanami, stanowiło radę wspólnoty (1QS VIII 1; 4Q265 7 II 7). Taka struktura odpowiada podziałowi Izraela w czasie wędrówki przez pustynię w Lb 1-4: każde z dwunastu plemion (wliczając Efraima i Manassesa) zamieszkiwało w oddzielnym obozie, podczas gdy Lewici byli podzieleni na trzy klany i obozowali wokół Namiotu Spotkania (Lb 1,52-53). Zob. S. Hultgren, From the Damascus Covenant to the Covenant of the Community. Literary, Historical, and Theological Studies in the Dead Sea Scrolls (StTDJ 66; Leiden-Boston, MA: Brill 2007) 314. Zob. także D. Flusser, Qumran und die Zwölf, Judaism and the Origin of Christianity (Jerusalem: Magnes 1988) 173-185; S. Pinès, Notes on the Twelve Tribes in Qumran, Early Christianity and Jewish Tradition, w: Messiah and Christos. Studies in the Jewish Origins of Christianity Presented to David Flusser on the Occasion of His Seventy-Fifth Birthday (red. I. Grünwald - S. Shaked G.G. Stroumsa) (TSAJ 32; Tübingen: Mohr Siebeck 1992) 151-154.

6 Np. E. Lohmeyer, Die Offenbarung des Johannes (Handbuch zum Neuen Testament 16; Tübingen: Mohr Siebeck 1926. $\left.{ }^{2} 1953\right)$ 70; G. B. Caird, A Commentary on the Revelation of St. John the Divine (BNTC; New York, NY: Harper and Row 1996) 96.

7 D.E. Aune, Revelation 6-16 (WBC 52B; Nashville, TN: Thomas Nelson 1998) 443: „particular group of Christians (including all ages and both genders) who have been specially protected by God from both divine plagues and human persecution just before the final eschatological tribulation begins and who consequently survive that tribulation and the great eschatological tribulation begins and who consequently survive that tribulation and the great eschatological battle that is the culmination of that tribulation".

8 R. Bauckham, The Book of Revelation as a Christian War Scroll, „Neotestamentica" 22 (1988) 21-28 = The Climax of Prophecy: Studies on the Book of Revelation (Edinburgh: T. \& T. Clark 1993) 217-229; id., The List of the Tribes of Revelation 7 Again, JSNT 42 (1991) 104-115 = The Jewish World around the New Testament. Collected Essays (Grand Rapids, MI: Baker Academic 2010) 161-174. 
ale także z dwunastu apostołów ${ }^{9}$. Sam fakt, że z każdego plemienia powołana jest ta sama liczba opieczętowanych każe widzieć tutaj symbolizm, a nie próbę odtwarzania realiów historycznych, gdyż spisy poszczególnych plemion w ST mówią o różnej ich wielkości (por. Lb $1,20-46 ; 26,1-51)^{10}$. Ostateczny zatem sens liczby i listy opieczętowanych jest symboliczny: liczba Izraela jest liczbą kompletną; Izrael objawia się tutaj w swej doskonałej pełni ${ }^{11}$.

Wróćmy jednakże jeszcze raz do semantyki terminu Izrael: etnicznie żydowski Izrael versus chrześcijański Izrael-Kościół. W Ap nie istnieje rzeczywiste rozdzielenie pomiędzy etnicznym Izraelem ST, złożonym z Żydów oczekujących na Mesjasza (propozycja 1) lub uznających już Mesjasza w Jezusie (propozycja 2), oraz Izraelem NT, składającym się z pogan i Żydów, którzy idą za Jezusem Mesjaszem (propozycje 3, 4, 5). W perspektywie autora Ap istnieje tylko jeden Izrael, który oddaje cześć Mesjaszowi-Barankowi, w doskonałym wypełnieniu wszystkich obietnic ST ${ }^{12}$; etniczni Żydzi, którzy nie idą za Baran-

9 Mury nowej Jerozolimy (Ap 21,12-17) stają na dwunastu warstwach fundamentu, na których wypisane są imiona dwunastu apostołów. Mury te mają także dwanaście bram, które są oznaczone imionami dwunastu plemion Izraela. Długość, szerokość i wysokość miasta to 12000 stadiów, a mur ma 144 łokcie. W świetle tej wizji liczba 144000 to dwanaście plemion Izraela pomnożonych przez dwanaście apostołów oraz przez tysiąc. O symbolice liczby dwanaście w Ap zob. A. Geyser, The Twelve Tribes in Revelation: Judean and Judeo-Christian Apocalypticism, NTS 28 (1982) 388-399.

10 Przyimek '́K ma charakter dystrybutywny, który odsyła do „miejsca” pochodzenia opieczętowanych i funkcjonuje podobnie jak w bezpośrednim kontekście (Ap 7,9; por. 5,9) oraz w Lb 1,20-46, w spisie wojsk Izraela. Na ten ostatni szczegół zwraca uwagę Bauckham (“Christian War Scroll”, 22) który twierdzi, że wielokrotnie powtórzona formuła z Ap 7,5-8,

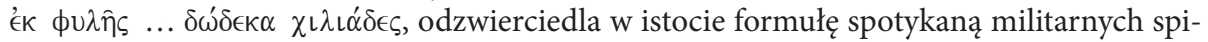

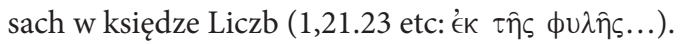

11 Zob. G.K. Beale, The Book of Revelation. A Commentary on the Greek Text (NIGTC; Grand Rapids, MI - Cambridge, U.K.: Eerdmans / Carlisle, U.K.: Paternoster 1999) 416: „Many commentators rightly understand the number to be firgurative, since nearly all other numbers in the book have figurative significance. Here, the group who is sealed represents the complete number of God's people".

12 Zob. M. Wojciechowski, Church as Israel according to the Revelation of St. John, „Collectanea Theologica” 64 (1994) 33-40. Autor ten (ibid., 39-40) stwierdza: „[W] cannot find any discontinuity or state that the servants of the Lamb were sharply distinguished from Israel. If we call the new community the Church, we must immediately add that it appears as identical with Israel, even if transformed and knowing the Messiah. According to the Book of Revelation the people of all the nations, races and languages who believe in Him, enter the Israel of the twelve tribes and become true Jews. It is not a 'new Israel' different from the old one, but the same People of God. We can even suggest that the author of the Revelation would prefer to call the community of all Christians Israel rather than the Church, applying the word 'church' ekklesia to local churches (Rev 1,3;22,16); and as for the Christians, 
kiem (Ap 14,4), nie są w istocie prawdziwymi Żydami, ale synagoga Szatana $(2,9 ; 3,9)^{13}$. Dlatego nie są uprawnione dwie pierwsze propozycje, które ograniczają tożsamość opieczętowanych do etnicznego Izraela, jak i trzy ostatnie, które ograniczają się jedynie do współczesnych, czy też przyszłych chrześcijan. W wizji tej zacierają się granice czasowe między przeszłością, teraźniejszością i przyszłością; wizja opisuje wieczne teraz, które jest czasem ostatecznym. Opieczętowanych należy widzieć jako odrodzony Izrael: zjednoczony lud Pierwszego Przymierza (reprezentowany przez 12 plemion) oraz lud Nowego Przymierza (reprezentowany przez 12 apostołów Baranka). To połączenie symbolizowane jest na kartach Apokalipsy przez obecność 24 starców $(12+12)$, którzy zasiadają na tronach wokół tronu Baranka. Cały Izrael, złożony zarówno z pogan, jak i Żydów, oddaje cześć Bogu i Barankowi w nowej Jerozolimie. W tym sensie 144000 opieczętowanych może być identyfikowanych, wbrew niektórym komentatorom, $\mathrm{z}$ tą samą liczbą opieczętowanych opisaną w 14,1-5, jak i niepoliczalnym tłumem $z$ każdego narodu i wszystkich pokoleń, ludów i jezyków opisanym w bezpośrednim kontekście następującym (7,9-17). Odrodzenie i zjednoczenie dwunastu pokoleń Israela na końcu czasów, jak i wejście pogan do Izraela, były ważną częścią oczekiwań wyrażonych w ST, żywych również $\mathrm{w}$ okresie powstania $\mathrm{NT}^{14}$. Wypełnienie się tych oczekiwań poprzez misję Jezusa stoi u podstaw koncepcji odrodzonego Izraela w Ap.

he would likely call them Jews... The integration of the community of the saved with Israel is presented in the eschatological perspective. It results from the general character of the book and not from an idea that Israel and the Church would be separated now and reunited in the future. Nothing suggests any separation; the same crowd of the saved is described as Israel and as a multitude of the servants of the Lamb. The eschatology is not a science of the future; what is historically 'tomorrow' explains 'today'. The Israel of the Book of Revelation is defined by the universal and salvific destiny awaiting the twelve tribes".

13 O tym, że prawdziwym Żydem jest także wierzący poganin, zobacz Rz 2,28-29; Ga 3,28-29.

14 Testament Benjamina 9,2 stwierdza: i tam [w świątyni Boga] dwanaście plemion $i$ wszyscy poganie będa zebrani razem. Co do idei odrodzenia dwunastu plemion zob. Is 11,10-13; 27,12-13; Jr 31,7-9; Ez 37,15-23; Syr 36,11; Tb 13,13-18; 2 Baruch 78,5-7; Testament Józefa 19,1-7; Mt 19,28; m. Sanhedrin 10,3; j. Sanhedrin 10,6. Koncepcja, iż poganie nawróceni na judaizm stają się prawdziwymi Izraelitami znajduje się w Wj 12,37-38; Rut; 2 Sm 11. Związanie jej z odnowieniem Izraela w czasach ostatecznych jest widoczne w Ps 47,9; 87; Is 66,19-21; Za 2,11; 8,23; 9,7; 14,16-19. Warto zwrócić także uwagę na obecność prorokini Anny w Łk 2,36-38. Miała ona pochodzić z pokolenia Asera, a zatem z jednego z dziesięciu „zaginionych” plemion. Pojawia się ona na samym początku misji Jezusa jako profetyczny znak nadejścia eschatologicznej pełni czasów naznaczonej zjednoczeniem dwunastu plemion rozproszonych po świecie (Mt 19,28; Łk 22,30; por. Iz 49,6). 


\title{
Kolejność imion plemion w liście Ap 7,5-8
}

Nie istnieją poważne wątpliwości co do obecnej greckiej formy tekstu listy w Ap 7,5-8 ${ }^{15}$. Plemiona wymienione są w niej w następującej kolejności:

\author{
Juda-Ruben \\ Gad-Aser \\ Neftali - Manasses \\ Symeon - Lewi \\ Issachar - Zabulon \\ Józef-Beniamin
}

Przegląd starotestamentowych i pozabiblijnych list dwunastu plemion pokazuje, że powyższa lista nie znajduje w nich swego dokładnego odpowiednika. Co więcej, lista ta wymyka się metodologicznemu rozróżnieniu na listy stworzone na podstawie klucza genealogicznego oraz na listy odwołujące się do podziału terytorialnego. Próbując zrozumieć listę, używając klucza genealogicznego, pierwsza para to synowie Lei, następna to synowie jej niewolnicy Zilpy, trzecia para to Neftali, który jest synem Bilhy, niewolnicy Racheli, oraz Manasses, wnuk Racheli. Pozostałą część listy tworzą czterej synowie Lei oraz dwaj synowie Racheli. Sekwencja ta nie odpowiada kolejności, w jakiej synowie Jakuba-Izraela przychodzili na świat ( $R d z 29,32-30,24 ; 35,17-18$; por. Jub. 28,17-24; 32,3), a więc: czterej synowie Lei (Ruben, Symeon, Lewi, Juda), dwaj

15 Jedynie dwa mss (numery 1854 i 2845), datowane na średniowieczne (XI w., Iviron at Mt. Athos, i XV w., Oxford Bodleian Library), wymieniają plemię Dana na miejscu Gada. C. von Tischendorf (Novum Testamentum graece ad antiquissimos testes denuo recensuit, apparatum criticum omni studio perfectum apposuit commentationem isagogicam praetexuit. Editio octava critica maior [Lipsiae: Giesecke \& Devrient 1869-1872] II, 946) podaje jeszcze dwa inne mss z taką lekcją; jeden przechowywany w Liceum we Frankfurcie nad Odrą, a drugi w miejskiej bibliotece w Hamburgu. Zmiana ta jest najprawdopodobniej zwykłym błędem kopisty wynikłym z zastąpienia krótkiej trzyliterowej nazwy $\gamma \alpha ́ \delta$, inną równie dobrze znaną ze ST trzyliterową nazwą plemienia $\delta \alpha$ 'v. Zamierzona korekta tekstu wydaje się mało prawdopodobna, gdyż wstawienie Dana, którego nie ma w liście, kreuje nową trudność polegającą na nieobecności Gada. Jeden ms (nr 1957, XV w., Biblioteka Watykańska), zachowując te same imiona, podaje je w nieco innej kolejności: Juda, Gad, Neftali, Symeon, Issachar, Józef, Ruben, Aser, Manasses, Lewi, Zabulon, Beniamin. Kolejność ta nie ma swego odpowiednika w żadnej liście starotestamentowej. Inny ms z rodziny $f^{13}$ (nr 69, XV w., przechowywany w Leicester Record Office) pomija zupełnie pokolenie Józefa dając w efekcie listę jedenastu plemion. Por. The Center for New Testament Textual Studies NT Critical Apparatus, The New Orleans Baptist Theological Seminary, 2004 (BibleWorks 9). 
synowie Bilhy (Dan, Neftali), dwaj synowie Zilpy (Gad i Aser), kolejni dwaj synowie Lei (Issachar i Zabulon), synowie Rachaeli (Józef i Beniamin). Zdumiewające, że sekwencja narodzin nie jest odtworzona w żadnej liście znajdującej się w ST oraz literaturze okołotestamentalnej.

Brak właściwej kolejności (tj. powielającej wzory znanych nam list starotestamentowych i okołotestamentalnych), jak i zrozumiałej kolejności (tj. brak klucza genealogicznego, czy też terytorialnego, według którego lista ta została skomponowana) może prowadzić do wniosku, że lista jest wynikiem błędu autora lub późniejszych kopistów lub też ta zupełnie nowa sekwencja obecna w liście jest zamierzona. Przyjęcie pierwszej możliwości, wraz z rekonstrukcją hipotetycznej „oryginalnej” listy, jest jednak uprawnione dopiero wówczas, gdy zostaną wyczerpane wszelkie możliwości zrozumienia obecnej sekwencji plemion, występującej w dostępnym nam tekście Ap.

\section{Zamierzona nowość listy}

Według H. Grotiusa, brak zachowanego porządku w liście objawia prawdę, że w Chrystusie wszyscy są równi: „Nullus servatur ordo, quia omnes in Christo pares" ${ }^{\prime 6}$. Kolejność plemion w liście jest zatem świadomym odejściem od znanych sekwencji, których celem jest wskazanie na nową rzeczywistość mistycznego Ciała Chrystusa, gdzie ostatni są pierwszymi, a pierwsi ostatnimi.

Do podobnych wniosków doszli także późniejsi komentatorzy. Ograniczmy się do zacytowania jedynie dwóch, których dzieli ponad 120-letni przedział czasowy. E. W. Hengstenberg twierdzi, że kompletne pomieszanie synów żon i niewolnic Jakuba jest zamierzone; wskazuje ono, że „in the kingdom of Christ difference of birth, external privilege avails nothing; the same principle, on which the doctrine of Paul in Eph. iii.6 rests, 'That the Gentiles should be fellow-heirs and of the same body, and partakers of his promise in Christ by his Gospel"'17. Lista wskazuje na uniwersalizm opieczętowanych; nie liczy się ich pogańskie, czy też żydowskie pochodzenie. Brak wśród dwunastu plemion Dana pokazuje, że lista nie jest odwzorowaniem starego „żydowskiego” Izraela, ale nowego, „żydowsko-chrześcijańskiego” ${ }^{18}$. Umieszczenie Manassesa, syna umiłowanej Racheli, pomiędzy synami „znienawidzonej” Lei (włączając w to

16 H. Grotius, Annotationes in Novum Testamentum. Denuo emendatius editae (Groningen: Zuidema 1830) VIII, 304.

17 E.W. Hengstenberg, The Revelation of St. John Expounded for Those Who Search the Scriptures (Edinburgh: T. \& T. Clark 1851) I, 302.

18 Ibid., 297. 
także synów jej niewolnicy) pokazuje równość wszystkich pokoleń ${ }^{19}$. Fakt, że synowie niewolnic, Gad, Aser i Neftali, zajmują wysoką 3, 4 i 5 pozycję na liście - umieszczeni są nawet przed synami umiłowanej Racheli - ma sygnalizować włączenie pogan do wspólnoty nowego Izraela ${ }^{20}$.

G.E. Ladd uznał, iż nieregularności występujące w liście, głównie brak Dana, każą myśleć, że lista ta nie jest widziana przez autora Apokalipsy jako rzeczywiste przedstawienie dwunastu plemion starotestamentowego Izraela. W konsekwencji stwierdza on: „No satisfactory explanation of this irregular list of names has been offered, unless it be this: John intends to say that the twelve tribes of Israel are not really literal Israel, but the true, spiritual Israel - the church"21. Odstępstwa od spodziewanego układu listy, a zatem nowa lista, ma wskazywać na zupełnie nowa rzeczywistość, którą jest Kościół.

Pierwszeństwo Judy, który występuje przed pierworodnym Rubenem, ma już swoje wcześniejsze paralele w ST (zob. Lb 2,3-31; 7,12-78; 10,14-27; 34,19-28; Joz 21,4-7.9-38; Sdz 1,2-35; 1 Krn 2-9; 6,50-66; 12,25-38). W niektórych przypadkach pierwszeństwo Judy wynikało z geograficznego klucza, w którym sporządzano listę; zaczynano od położonego najbardziej na południe pokolenia Judy i przesuwano się na północ (por. Lb 34,19-28; Joz 21,4-7 oraz 21,9-38; Sdz 1,2-35; 1 Krn 6,50-66; 12,25-38). W pozostałych przypadkach można przypuszczać, iż pierwszeństwo Judy wynikało z dominującej roli

19 Ibid., 303.

20 Dla niektórych komentatorów (Hengstenberg, Swete) nie bez znaczenia jest także faktor geograficzny. Zob. C.R. Smith, The Portrayal of the Church as the New Israel in the Names and Order of the Tribes in Revelation 7.5-8, JSNT 39 (1990) 114-115. Autor ten zauważył, że Gad, Aser, Neftali oraz Manasses to plemiona mieszkające pośród pogan na północy i związał to z koncepcją Galilei pogan z Iz 9,1 (tekst cytowany w Mt 4,13) i szczególnie intensywną działalnością Jezusa w tym regionie. $\mathrm{W}$ istocie plemionami cytowanymi wraz z wyrażeniem Galilea pogan są Neftali i Zabulon, a plemiona Gada, Asera i Manassesa nie mieszkały w Galilei. Zob. R. Bauckham, The List, 101. Bez wątpienia argument z pomieszania dzieci z poszczególnych matek, jako znak równości plemion, ma swoją obiektywną wartość. Twierdzenie jednak, iż wysoka pozycja synów niewolnic jest znakiem włączenia pogan w nowy Izrael, budzi zastrzeżenia Bauckhama (ibid.). W jego opinii twierdzenie to może mieć jedynie wartość subiektywnego przypuszczenia komentatora. C.R. Smith (The Tribes of Revelation 7 and the Literary Competence of John the Seer, JETS 38 [1995] 217) w „promocji” synów niewolnic widzi , an attempt to depict the admission to privilege of those born low”. W tym sensie, synowie niewolnic, jako nisko urodzeni, mogą reprezentować wszystkich, którzy przez fakt urodzenia nie mieli takich samych przywilejów. W sensie teologicznym zatem plemiona niewolnic mogą reprezentować pogan, którzy przez fakt urodzenia się poza Narodem Wybranym, nie uczestniczyli w jego obietnicach.

21 G.E. Ladd, A Commentary on the Revelation of John (Grand Rapids, MI: Eerdmans 1972) 115. 
dynastii Dawida wywodzącej się z tegoż plemienia. R. Bauckham twierdzi, że motyw dawidowego mesjanizmu mógł przyświecać Pseudo-Filonowi w LAB 25,4 oraz 25,9-13, gdzie zamieścił listę dwunastu plemion z Judą na pierwszej pozycji. Pseudo-Filon gloryfikuje Kenaza, z plemienia Judy, jako pierwszego i największego sędziego (25,9; por. Sdz 3,9), prekursora Dawida $(21,4-5 ; 49,1)$, prototyp przyszłego mesjańskiego wybawcy Izraela z rąk pogan ${ }^{22}$. Według wizji Ez 37,15-25 plemiona północne (Izrael) będą przyłączone do Judy i będzie nad nimi panował nowy Dawid z plemienia Judy (por. Ez 34,23-25). Proroctwo to kontynuuje ideę zawartą już w Rdz 49,8, gdzie Jakub zapowiada moment, w którym jedenaście pozostałych plemion złoży pokłon przed Judą. Rdz 49,10 poszerza perspektywę, przepowiadając, iż Juda zdobędzie posłuch wśród narodów (MT) oraz jest oczekiwaniem narodów (LXX). W przypadku Ap 7,5 fakt pochodzenia Mesjasza z plemienia Judy wydaje się najbardziej racjonalną przyczyną dla wyjaśnienia pierwszej pozycji tego plemienia na liście. W istocie

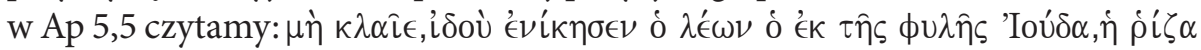
$\Delta \alpha u$ í - Przestań płakać! Oto zwyciężył Lew z pokolenia Judy, Odrośl Dawida ${ }^{23}$. Plemię, z którego pochodzi głowa Izraela (por. Ef 1,22; 4,15; Kol 1,18; 2,19) Izraela złożonego z wszystkich narodów, ludów, plemion i języków (por. Ap 5,9; 7,9) - znajduje się zatem na pierwszej pozycji.

W wyniku upadku dynastii Dawida ${ }^{24}$ oraz zwycięskiego powstania Machabeuszy dominującą rolę polityczną i religijną w Izraelu okresu Drugiej Świątyni odgrywało plemię Lewiego. Patrząc na żydowską okołotestamentalną literaturę apokaliptyczną, która poświadcza prymat plemienia Lewiego, można by słusznie oczekiwać imienia „Lewi” na pierwszej pozycji ${ }^{25}$. Znaczenie tego plemienia nie jest jednak odzwierciedlone w sekwencji imion listy Janowej, gdzie zajmuje dopiero ósmą pozycję ${ }^{26}$. Jeśli patrzeć na listę w Ap 7,4-8 z punktu widzenia te-

22 R. Bauckham, The List, 111-112.

23 Por. Ap 3,7; 22,16. Zob. także Hbr 7,11.

24 Bezpośredni udział dynastii Dawida w zarządzie perskiej prowincji Yehud przypada na lata 520-490 przed Chr. i kończy się z osobą Selomit, córki Zorobabela (1 Krn 3,19). Zob. E. M. Meyers, The Shelomith Seal and Aspects of the Judean Restoration: Some Additional Reconsiderations, ErIs 18 (1985) 33* $38^{\star}$.

25 Lewi jest pierwszy w liście 11Q19 XXIV 11-16. W Testamencie Judy 25,1, w porządku plemion mających dostąpić zmartwychwstania, pierwszy wymieniony jest Lewi, a potem Juda. Zob. C.R. Smith, The Tribes, 215-216.

26 Tekst syryjski poświadczony przez manuskrypt Nitran (British Museum, Ms. Add. 17193) pomija imię Lewiego; dopiero późniejsza ręka dodaje jego imię na marginesie. Tekst syryjski zawarty w manuskrypcie Crawford (Library of the Earl of Crawford, Ms. Syr. 2) natomiast wymienia Lewiego po Issacharze, a więc dopiero na 9 pozycji. Gwynn twierdzi, iż wspólne źródło dla obu mss nie zawierało imienia Lewiego. Zob. J. Gwynn, The Apocalypse 
rytorialnego obecność plemienia Lewiego może nawiązywać do eschatologicznej wizji z Ez 48,9-20. Tekst ten zawiera idealistyczną wizję przyszłego podziału kraju, w którym kapłani z rodu Sadoka, lewici oraz sam władca otrzymują przydział ziemi ${ }^{27}$. Brama Lewiego wzmiankowana jest także w Ez 48,31-34 oraz w qumrańskim Zwoju Świątyni (4Q19) jako jedna z dwunastu bram nowej Jerozolimy oznaczonych imionami epigonów dwunastu szczepów Izraela (por. Ap 21,12 ${ }^{28}$. W ujęciu Ap, gdzie w nowym Jeruzalem nie ma już świątyni i nie ma potrzeby sprawowania kultu ofiarniczego przez kapłanów i lewitów $(21,22)$, a wszystkim zbawionym przysługuje tytuł kapłana $(1,6 ; 5,10 ; 20,6)$, wspomnienie Lewiego na odległej pozycji pośród pozostałych plemion Izraela nie jest bez znaczenia. Uprzywilejowana rola potomków Lewiego, jako kapłanów, pośredników między Bogiem i Izraelem, zakończyła się wraz z ustaniem ważności ofiar starotestamentowych ${ }^{29}$.

of St. John, in a Syriac Version Hitherto Unknown (Dublin: Hodges, Figgis \& Co. - London: Longmans, Green \& Co. 1897) 58. Syryjskie teksty ss. 9 oraz 35. Wg Gwynna oba mss są świadkami zaginionego tłumaczenia Polikarpa dla biskupa Filokseniusa z Mabbug (508 r. po Chr.), tzw. Versio Philoxeniana. Inny jedyny znany nam syryjski tekst Ap, tłumaczenie Tomasza z Harkel (616 r. po Chr.), również poświadcza to przestawienie.

27 Imię Lewiego pojawia się w listach genealogicznych dwunastu plemion i jest pomijane w listach sporządzanych w kluczu terytorialnym, gdyż Lewi nie posiadał na własność żadnego terytorium. Wyjątkiem jest właśnie Ez 48,1-28, gdzie plemię Lewiego otrzymało przydział ziemi wokół nowej Jerozolimy. Bauckham („Christian War Scroll”, 21-28, esp. 24) proponuje inny podział starotestamentowych list i twierdzi, iż Lewi nie występuje w listach o znaczeniu militarnym (np. Lb 1,49; 2,33; 26,1-51; 1 Krn 21,6), ale jest podawany w listach o znaczeniu niemilitarnym (Lb 3,14-39; 26,57-62). Co ciekawe, lista w Ap 7,5-8 ma wydźwięk militarny i mimo to podaje imię Lewiego. Jej odpowiednikiem byłaby qumrańska Reguła Wojny (I,2; IV,1-8) gdzie wśród dwunastu pokoleń uczestniczących w eschatologicznej wojnie wymieniany jest także Lewi.

28 Wg rekonstrukcji E. Puecha brama Lewiego występuje także wśród bram nowej Jerozolimy w 4Q554. Zob. E. Puech, The Names of the Gates of the New Jerusalem (4Q554), w: Emanuel. Studies in Hebrew Bible, Septuagint and Dead Sea Scrolls in Honor of Emanuel Tov (red. S.M. Paul - R.A. Kraft - L.H. Schiffman - W.W. Fields - E. Ben-David) (VT.S 94; Leiden: Brill 2003) 379-392 (Symeon - [Lewi] - [Judah] - Józef - [Benjamin] - Ruben [Issachar] - [Zabulon] - [Gad] - [Dan] - Neftali - Aser).

29 W tym miejscu warto zacytować stary komentarz J. A. Bengela (3 wyd. z 1758): „After the Levitical ceremionies were abolished, Levi found himself again on a level with his brethren. All now are priests, all have access, not one through another, but one with another. Levi was chosen of old for the public ministrations of the sanctuary, and the priesthood in particular was given to Aaron and his posterity; but in the New Testament such shadowwork is passed away, and Levi hence became as one of the other tribes". Za E.W. Hengstenberg, Revelation, I, 302. 
Wysoka pozycja Rubena na liście, pierworodnego syna Jakuba, jest wyjaśniona przez C. R. Smitha na sposób symboliczny: „As the first-born, the represents believing Israelites, those who, like the first-born in the Old Testament, 'belong to the Lord' (Exod. 13.2)" ${ }^{30}$. Prócz Judy i Rubena, Smith podkreśla również typologiczne znaczenie obecności w liście wszystkich sześciu pozostałych synów żon Jakuba, Lei i Racheli: „Significantly, the six other 'non-handmaid' tribes (i.e. the sons of the 'true wives') are not deleted, but included later in the list, typifying the eventual salvation through the church of the 'fullness of Israel' (Rom.9-11)"31. Ostatnia pozycja Benjamina, która ma swoje paralele w ST, ma również swoje znaczenie. G. K. Beale wskazuje na Midrasz Rabba 98,2 który odnosi wezwanie do zgromadzenia się synów Jakuba w Rdz 49,1 do eschatologicznego odrodzenia Judy i Benjamina; będzie to moment, w którym inne plemiona oddadzą im hołd. Pozycja Judy i Benjamina w liście Ap tworzy literacką

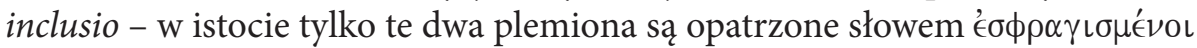
(opieczętowani) - która wskazuje na ważność zarówno pierwszego, jak i ostatniego plemienia ${ }^{32}$.

\section{„Prehistoria" listy, czyli próby rekonstrukcji Vorlage}

G. B. Gray twierdził, że niezrozumiała kolejność, w jakiej występują plemiona, jest wynikiem błędu, a dokładnie transpozycji, która wkradła się w procesie transmisji tekstu. Prawidłowa, a zatem pierwotna, kolejność wymaga przesunięcia całej sekwencji Gad, Aser, Neftali, Manasses (ww. 5c-6) na sam koniec obecnej listy (po w. 8) ${ }^{33}$. Otrzymujemy wówczas kolejność według klucza genealogicznego (kolumna pierwsza poniżej): najpierw sześciu synów z pierwszej żony Jakuba/Izraela, Lei, następnie dwaj synowie drugiej żony, Racheli, dalej dwaj synowie Zilpy, niewolnicy Lei, oraz na końcu dwóch synów Bilhy, niewolnicy Racheli. Z przyczyn, które omówimy poniżej, w obecnym tekście mamy jednak na miejscu Dana pokolenie Manassesa.

30 C.R. Smith, The New Israel, 115.

31 Ibid., 115.

32 Beale, Revelation, 417-418. Warto także zauważyć gramatyczną nieprawidłowość

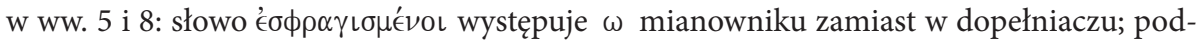
kreśla ona istnienie wspomnianej inclusio.

33 G.B. Gray, The List of the Twelve Tribes, „The Expositor”, $6^{\text {th }}$ series, 5 (1902) 225-240; id., The Tribes, w: Encyclopaedia Biblica. A Critical Dictionary of the Literary, Political and Religious History, the Archaeology, Geography, and Natural History of the Bible (red. T.K. Cheyne - J.S. Black) (New York, NY: Macmillan - London: Black 1903) IV, 5209. 


$\begin{array}{ll}\text { Juda } & \text { Juda } \\ \text { Ruben } & \text { Ruben } \\ \text { Symeon } & \text { Gad } \\ \text { Lewi } & \text { Aser } \\ \text { Issachar } & \text { Neftali } \\ \text { Zabulon } & \text { Manasses } \\ \text { Józef } & \text { Symeon } \\ \text { Benjamin } & \text { Lewi } \\ \text { Gad } & \text { Issachar } \\ \text { Aser } & \text { Zabulon } \\ \text { Neftali } & \text { Józef } \\ \text { Dan (/Manasses) } & \text { Benjamin }\end{array}$

Sekwencję: synowie żon (zawsze pierwsi synowie Lei i potem synowie i wnukowie Racheli) - synowie niewolnic, spotykamy w Rdz 35,23-26; Wj 1,2-4; Lb 1,5-16; 13,4-15; Pwt 33,6-25; Joz 13-19, a także u Józefa Flawiusza, Ant. I, 344; II, 177-183. W powyższych przykładach kolejność imion nie odpowiada jednak sekwencji znajdującej się w Ap ani w liście, którą zaproponował G.B. Gray jako Vorlage.

Możliwa jest także rekonstrukcja polegająca na przesunięciu tej samej sekwencji imion (Gad, Aser, Neftali, Manasses) za w. 8a. Otrzymamy wówczas następującą kolejność imion: wpierw wszyscy synowie Lei (Juda, Ruben, Symeon, Lewi, Issachar, Zabulon), następnie synowie niewolnicy Lei, Zilpy (Gad i Aser), synowie Bilhy (Neftali i Dan - na miejscu którego w tekście stoi Manasses), i na końcu synowie Racheli (Józef i Benjamin) ${ }^{34}$. Taka pierwotna sekwencja odpowiadałaby w przybliżeniu kolejności znanej z Rdz 49,3-27 - sześciu synów Lei, starszy syn Bilhy (Dan), dwaj synowie Zilpy, młodszy syn Bilhy (Neftali), dwaj synowie Racheli (kolumna pierwsza poniżej). Jeżeli tekst Rdz 49,3-27 służył jako Vorlage dla Ap 7,5-8 należałoby przyjąć w pierwszej fazie (1) świadome przesunięcie Judy na pierwszą pozycję oraz (2) powyższą transpozycję sekwencji czterech synów niewolnic (kolumna druga). Następnym krokiem byłoby (3) usunięcie imienia Dana i zastąpienie go imieniem Manassesa dla uzyskania

34 Obie rekonstrukcje podaje także w swym komentarzu R.H. Charles, A Critical and Exegetical Commentary on the Revelation of St John (ICC; Edinburgh: T. \& T. Clark 1920) I, 208. Uważa jednak, że pierwsza jest lepsza. 
liczby dwunastu plemion. Manasses, zgodnie z kluczem genealogicznym, zostałby umieszczony za Neftalim, bratem Dana. Ostatnim krokiem (4) byłaby zamiana sekwencji w parze Zabulon - Issachar na odpowiadającą kolejności urodzin.

$\begin{array}{lll}\text { Ruben } & \text { Juda } & \text { Juda } \\ \text { Symeon } & \text { Ruben } & \text { Ruben } \\ \text { Lewi } & \text { Dan } & \text { Gad } \\ \text { Juda } & \text { Gad } & \text { Aser } \\ \text { Zabulon } & \text { Aser } & \text { Neftali Manasses } \\ \text { Issachar } & \text { Neftali } & \text { Symeon } \\ \text { Dan } & \text { Symeon } & \text { Lewi } \\ \text { Gad } & \text { Lewi } & \text { Issachar Zabulon } \\ \text { Aser } & \text { Zabulon } & \text { Józef } \\ \text { Neftali } & \text { Issachar } & \text { Benjamin } \\ \text { Józef } & \text { Józef } & \\ \text { Benjamin } & \text { Benjamin } & \end{array}$

Powyższą sugestię G. B. Graya o transpozycji en bloc imion czterech synów niewolnic podjął C. R. Smith, rekonstruując możliwą trzystopniową ewolucję listy $^{35}$. Wychodzi on od listy ułożonej wg klucza genealogicznego: synowie Lei - synowie Racheli - synowie niewolnic, Zilpy i Bilhy (pierwsza kolumna poniżej). Ten sam klucz, tzn. wpierw synowie żon, a następnie synowie niewolnic, jest obecny w liście w Rdz 35,23-26, z tą różnicą jednak, że synowie Bilhy wymieniani są przed synami Zilpy. (Szczegół ten nie ma jednak znaczenia w świetle wielu wariacji kolejności w wymienianiu synów niewolnic Jakuba w ST). Kolejnymi krokami rekonstrukcji są: (1) zmiana pozycji Judy oraz (2) usunięcie Dana i zastąpienie go Manassesem (kolumna druga). Ostatnią zmianą jest przeniesienie en bloc czterech ostatnich imion na obecne miejsce w liście Janowej (kolumna trzecia). Każda z tych zmian miałaby znaczenie teologiczne (omówione powyżej), jako że nowa lista ma przedstawiać nowy Izrael, Kościół.

35 C.R. Smith, The New Israel, 114. Zob. także id., Tribes, 213-218. 


$\begin{array}{lll}\text { Ruben } & \text { Juda } & \text { Juda } \\ \text { Symeon } & \text { Ruben } & \text { Ruben } \\ \text { Lewi } & \text { Symeon } & \text { Gad } \\ \text { Juda } & \text { Lewi } & \text { Aser } \\ \text { Issachar } & \text { Issachar } & \text { Neftali } \\ \text { Zabulon } & \text { Zabulon } & \text { Manasses } \\ \text { Józef } & \text { Józef } & \text { Symeon } \\ \text { Benjamin } & \text { Benjamin } & \text { Lewi } \\ \text { Gad } & \text { Gad } & \text { Issachar } \\ \text { Aser } & \text { Aser } & \text { Zabulon } \\ \text { Dan } & \text { Neftali } & \text { Józef } \\ \text { Neftali } & \text { Manasses } & \text { Benjamin }\end{array}$

R. Bauckham sugerował, że podstawą listy Janowej była normatywna lista znajdująca się w $L A B$ 8,11-14; 26,10-11 i naśladująca sekwencję imion w Testamencie Dwunastu Patriarchów (pierwsza kolumna poniżej). Lista ta jednak poddana została kilku zmianom: (1) odwrócenie kolejności synów Bilhy i Zilpy $^{36}$, (2) przesunięcie Judy na pierwszą pozycję, jak w LAB 25,4 oraz 25,9-13, (3) jednoczesna obecność Manassesa i Efraima, poświadczona także przez $L A B$ 25,4 oraz $25,9-13$, (4) pominięcie Dana, w celu otrzymania liczby dwunastu plemion, oraz, w ostatecznej fazie (trzecia kolumna), (5) zastąpienie imienia Efraima przez Józefa i (6) transpozycja en bloc czterech imion (Gad - Manasses $)^{37}$.

$\begin{array}{lll}\text { Ruben } & \text { Juda } & \text { Juda } \\ \text { Symeon } & \text { Ruben } & \text { Ruben } \\ \text { Lewi } & \text { Symeon } & \text { Gad } \\ \text { Juda } & \text { Lewi } & \text { Aser } \\ \text { Issachar } & \text { Issachar } & \text { Neftali } \\ \text { Zabulon } & \text { Zabulon } & \text { Manasses } \\ \text { Dan } & \text { Gad } & \text { Symeon } \\ \text { Neftali } & \text { Aser } & \text { Lewi }\end{array}$

36 Kolejność ta w ST była rzeczywiście dowolna. Nie jest zatem konieczne wyjaśnianie tej zmiany, jak chce tego Bauckham (The List, 113), cytowaniem listy przez autora Ap z pamięci.

37 R. Bauckham, The List, 112-113. 


$\begin{array}{lll}\text { Gad } & \text { Neftali } & \text { Issachar } \\ \text { Aser } & \text { Manasses } & \text { Zabulon } \\ \text { Józef } & \text { Efraim } & \text { Józef } \\ \text { Benjamin } & \text { Benjamin } & \text { Benjamin }\end{array}$

W świetle powyżej prezentowanych propozycji hipoteza R. Bauckhama jest niepotrzebnie skomplikowana. Przynajmniej jedna sekwencja zmian jest mało prawdopodobna: wychodzimy od imienia Józefa, które zmieniamy na Efraim (aby w tekście mógł się pojawić Manasses), by ponownie wrócić do imienia Józef ${ }^{38}$.

A. Farrer twierdził, że listę Ap 7,5-8 trzeba czytać tak jak listę w Ez 48,31-34, czyli jako listę dwunastu bram nowej Jerozolimy oznaczonych imionami epigonów dwunastu plemion. Lista Janowa różni się jednak w sposób oczywisty od listy w Ez 48 sekwencją imion. Farrer zaproponował, by kolejne imiona w Ap 7,5-8 czytać w kolejności wyznaczanej przez sekwencję kierunków geograficznych bram nowej Jerozolimy z Ap 21,13, która w porównaniu do Ez 48 jest inna: Ez - północ, wschód, południe, zachód; Ap - wschód, północ, południe, zachód. Otrzymujemy wówczas następujący schemat:

Juda

(2) Ruben

(7) Symeon

(3) Gad

E

(8) Lewi

(4) Aser

NS

W

(9) Issachar

(5) Neftali

(10) Zabulon

(6) Manasses

(11) Józef

(12) Benjamin

38 Smith (Tribes, 217) słusznie pyta: ,if Joseph is to be restored to the list in place of one of his sons, why should he ever be dropped from the normative list in the first place in favor of two of his sons?" 
Farrer wskazuje następujące zależności występujące w schemacie: starsze plemiona Lei (Ruben, Juda, Symeon) znajdują się naprzeciw plemion Racheli (Manassesa, Benjamina i Józefa), podczas gdy młodsze plemiona Lei (Lewi, Issachar, Zabulon) znajdują się naprzeciw plemion niewolnic (Gad, Aser, Neftali $^{39}$. Oczywistym niedociągnięciem tej interpretacji jest zakwalifikowanie Lewiego do „młodszych” plemion Lei, podczas gdy Juda, zaliczony do „starszych" plemion Lei, jest w istocie młodszy od Lewiego. Winkle zarzucił także tej interpretacji skoncentrowanie się jedynie na kierunkach geograficznych i zupełne pominięcie faktu przyporządkowania do każdego kierunku trzech bram. W jego mniemaniu, należałoby raczej użyć systemu kierunków geograficznych w połączeniu $\mathrm{z}$ systemem bram lub też samego systemu bram ( $\mathrm{z}$ inną sekwencją kierunków) bazującego na $\mathrm{Ez} 48^{40}$.

W opinii Winklea rzeczywistym Vorlage listy Janowej jest Ez 48,31-34 (pierwsza kolumna poniżej). Takie Vorlage wyjaśnia obecność Lewiego oraz Józefa w liście Ap. Winkle zaproponował, aby czytać listę Ezechiela w zmienionej kolejności kierunków geograficznych; zamiast oryginalnej kolejności: północ - wschód - południe - zachód, winniśmy przyjąć dokładnie odwrotną sekwencję kierunków: północ - zachód - południe - wschód (kolumna druga) ${ }^{41}$. Tak otrzymana lista ma wiele punktów zbieżnych z listą w Ap 7,5-8 (trzecia kolumna).

\begin{tabular}{cl|ll|l}
$\mathbf{N}$ & $\begin{array}{l}\text { Ruben } \\
\text { Juda }\end{array}$ & $\mathbf{N}$ & Ruben & Juda \\
& & Juda & Ruben \\
& & Lewi & & Gad
\end{tabular}

39 A. Farrer, The Revelation of St. John the Divine. Commentary on the English Text (Oxford: Clarendon 1964) 106-107.

40 R.E. Winkle, Another Look at the List of Tribes in Revelation 7, AUSS 27 (1989) 55.

41 Co do wyboru takiego „kierunku” czytania listy w Ez 48,31-34, Winkle („Another Look", 59-60) daje wysoce spekulatywne wyjaśnienia: (1) Zwyczajnie odwrócenie kolejności kierunków (W - S - E - N) umiejscowiłoby Judę na końcu listy; byłoby to jednak niedopuszczalne ze względu na Jezusa, postać centralną w Ap, który pochodzi z Judy. (2) Utrzymanie kierunku północnego na pierwszej pozycji, może być także wyjaśnione przez fakt, że wizje w Ap 4-5 miałyby być związane ze stołem chlebów pokładnych, który znajduje się w północnej części miejsca świętego. Jeśli idzie o sam fakt „odwrotnego" czytania sekwencji starotestamentowej, jaką miałby zastosować tutaj autor Ap, przykład tego mamy w Ap 13,1-2, gdzie odwrócona jest sekwencja występująca w Dn 7,3-8.19-20 (lew, niedźwiedź, pantera, 10 rogów). 


\begin{tabular}{ll|ll|l} 
E & Józef & W & Gad & Aser \\
& $\begin{array}{l}\text { Beniamin } \\
\text { Dan }\end{array}$ & & $\begin{array}{l}\text { Asher } \\
\text { Neftali }\end{array}$ & Neftali \\
& & & & Manasses \\
S & Symeon & S & Symeon & Symeon \\
& Issachar & & Issachar & Lewi \\
& Zabulon & & Zabulon & Issachar \\
& & & & \\
W & Gad & E & Józef & Zabulon \\
& Aser & & Beniamin & Józef \\
& Neftali & & Dan & Beniamin
\end{tabular}

Aby jednak odwrotnie czytana lista z Ez 48,31-34 przybrała kształt listy znanej nam z Ap 7,5-8, autor Ap musiał dokonać kilku zmian. Wpierw (1) nastąpiło usunięcie plemienia Dana ze względów teologicznych (omówimy je poniżej). Następnym koniecznym krokiem było przeorganizowanie listy za pomocą klucza genealogicznego. W efekcie, (2) Lewi musiał być przesunięty, by tworzyć parę ze swym bratem Symeonem, (3) a jedyny „osierocony” epigon, Neftali, otrzymał do pary swego najbliższego możliwego krewnego, Manasse$\mathrm{sa}^{42}$. Ostatnim zabiegiem (4) było przesunięcie Judy na pierwszą pozycję, również ze względów teologicznych.

\section{Résumé: nowość czy przypadek?}

D.E. Aune czyni bardzo ciekawe spostrzeżenie, że przy całej różnorodności list dwunastu synów Jakuba-Izraela oraz dwunastu plemion Izraela znajdujących się w ST, niezwykle rzadko zachodzi przypadek powtórzenia się tej samej listy

42 Winkle (ibid., 58) przedstawia szereg przekonywających argumentów za umieszczeniem Manassesa razem z Neftalim: „This is the only viable position for Manasseh for the following reasons: (1) Since Joseph is paired with Benjamin, the next closest relative with whom Manasseh could be paired was Naphtali, his foster-uncle (i.e., Jacob's son by Bilhah, Rachel's handmaid; Naphtali was in essence Rachel's 'foster-son'); (2) Naphtali had no close relative other than Manasseh with whom to be paired; (3) because Dan was Naphtali's full brother, the two tribes were normally associated together in genealogical and tribal lists; and (4) Manasseh was historically associated with the West [Num 2:3-21], which is just where this tribe ends up in the list in Rev. 7". 
w zakresie sekwencji (a czasem także liczby) podawanych imion ${ }^{43}$. Konsekwentnie, nie istniała zdogmatyzowana, raz ustalona i powszechnie powielana, kolejność. Ergo, obecność w Apokalipsie Janowej zupełnie nowej sekwencji imion nie powinna budzić zdziwienia. $\mathrm{Z}$ drugiej jednak strony, istnieją przykłady list w starożytnej żydowskiej literaturze pozabiblijnej, gdzie cytuje się dokładnie listy starotestamentowe ${ }^{44}$ lub powiela się po wielokroć własną nową sekwencję, dając jej ostatecznie status normatywnej listy ${ }^{45}$. Wydaje się nieprawdopodobne, aby autor Ap, który, jak mamy tego wielokrotne dowody, doskonale znał ST, mógł błędnie zestawić Manassesa z Neftalim i Symeonem, zapominając o jego powiązaniu z Józefem czy Beniaminem. Innymi słowy, zważając na autorytet pism natchnionych w pierwotnym Kościele, jakiekolwiek odstępstwo od zawartego tam tekstu (a więc także listy dwunastu plemion), jeśli nie jest jedynie błędem wynikłym $\mathrm{z}$ transmisji tekstu, winno mieć swe uzasadnienie. Nadto, biorąc pod uwagę charakter dzieła, jakim jest Ap, gdzie nawet najmniejszy detal ma swoje znaczenie, winniśmy odrzucić stanowisko, które utrzymuje, że lista jest dziełem przypadku ${ }^{46}$. Lista Janowa jawi się jako świadome przepracowanie znanych starotestamentowych sekwencji imion dwunastu epigonów (najprawdopodobniej znajdujących się w Rdz 49,3-27 lub Ez 48,31-34) na podstawie własnych założeń teologicznych autora Ap.

43 Aune, Revelation 6-16, 464. W Rdz 35,23-26 oraz Wj 1,2-4 sekwencja imion jest identyczna; druga lista wymienia braci przybywających do Egiptu, więc brakuje w niej Józefa, który jest już w Egipcie. Ta sama sekwencja imion występuje także w trzech listach: Lb 2,3-31; 7,12-78; 10,14-27 - Juda, Issachar, Zabulon, Ruben, Symeon, Gad, Efraim, Manasses, Beniamin, Dan, Aser, Neftali.

44 Józef Flawiusz w Ant. 2, 177-183, Pseudo-Filon w LAB 8,6 oraz Jub. 33,22 kopiują listę z Rdz 35,23-26. Inny przykład to lista z Rdz 46,8-27, która jest odtworzona w Jub. 44,11-34.

45 Sekwencja, w jakiej występują imiona epigonów dwunastu pokoleń w Testamentach Dwunastu Patriarchów, była bezsprzecznie popularna (jeśli nie normatywna) skoro występuje w LAB 25,4; 25,9-13; Jub. 34,30, Tg. Frg. Wj 28,17-20; Tg. Neof. Wj 28,17-20; 39,10-13 oraz Midraszu Rabba (Wj 38,8-9; Lb 2,7). Sekwencja odpowiada kolejności narodzin poszczególnych patriarchów, z pogrupowaniem wg klucza kolejnych matek: Lea, Bilha, Zilpa, Rachela. Bauckham (The List, 111) mówi o istnieniu dwóch normatywnych list w czasach NT: „[T]ere seem, in the first century CE, to have been two standard ways of listing the tribes. Both were matriological, grouping all the sons of each mother together. One, preferred by Josephus, gave precedence to the sons of the wives over the sons of the handmaids. The other, which seems to have been more popular, was a matriological modification of the order of birth, and seems to have been treated as the order of birth".

46 R.H. Mounce (The Book of Revelation [NICNT; Grand Rapids, MI: Eerdmans 1977] 170) zauważa: „there seems to be no particular reason for the order in which the tribes are given". 


\section{Dobór imion plemion w liście Ap 7,5-8}

W doborze imion epigonów dwunastu plemion zastanawiają dwa fakty. Pierwszy, to obecność Manassesa, przy jednoczesnym braku jego brata Efraima i, najbardziej zaskakującej w tym kontekście, obecności jego ojca Józefa. Drugi znak zapytania wiąże się z nieobecnością Dana, jednego z dwunastu synów Jakuba-Izraela i protoplasty jednego $\mathrm{z}$ dwunastu plemion Izraela.

\section{Enigmatyczna obecność Manassesa i nieobecność Efraima}

Czytając Janową listę dwunastu plemion zastanawia jednoczesna obecność syna i ojca, Manassesa i Józefa. Z reguły w listach dwunastu plemion w ST i literaturze okołotestamentalnej spotykamy albo Józefa i Beniamina, synów Racheli, albo braci Manassesa i Efraima, synów Józefa. Z trzema wyjątkami (Ez 48,1-28; 1 Krn 12,25-38; 27,16-22), ci ostatni występują w listach, w których nie ma pokolenia Lewiego i jest potrzeba uzupełnienia wykazu plemion do liczby dwunastu. Jeśli w wykazie jest już ojciec, wzmianka o synu wydaje się zbyteczna. Z jednym możliwym wyjątkiem (Lb 13,4-15), nie ma w ST i literaturze okołobiblijnej list podających jednocześnie Józefa i jednego, bądź obu, jego synów ${ }^{47}$. Jeśli założyć, iż autor chciał wymienić imiona epigonów w kluczu genealogicznym, to obserwujemy dwie anomalie: (1) spośród wszystkich synów Jakuba brakuje jedynie Dana, oraz (2) w liście występuje Manasses, który nie jest synem Jakuba, ale jego wnukiem. Można zatem wysnuć wniosek, iż Manasses został wpisany na miejsce Dana ${ }^{48}$. Wniosek taki nasuwa się również, gdy czytamy listę w systemie dwójkowym: wszystkie pary, prócz Neftali - Manasses, ułożone są w kluczu genealogicznym. W obecnym kształcie listy Manasses jest wymieniony po Neftalim, a zatem przyjmując, iż Manasses stoi na miejscu Dana, wzmiankowanie Dana po swoim bracie Neftalim jest zgodne z kluczem genealogicznym; otrzymujemy sekwencję dwóch synów jednej matki, Bilhy, niewolnicy Racheli. Fakt, iż starszy Dan miałby następować po młodszym Ne-

47 Lista w Lb 13,4-15 wzmiankuje wpierw Efraima (w. 8), a następnie Józefa i Manassesa (w. 11). Wzmiankę o Manassesie należałoby rozumieć jako glosę wyjaśniającą: $z$ pokolenia Józefa (czyli z pokolenia Manassesa). Ostatecznie zatem tekst, pomimo wzmianki o Józefie, mówi o plemionach dwóch synów Józefa: Efraimie i Manassesie.

48 Warto także zauważyć, iż tekst koptyjski (bohairycki) w miejsce Manassesa znajdującego się w tekście greckim wymienia imię Dana. Zob. NA ${ }^{27}$, ad loc.; C. von Tischendorf, Novum Testamentum, II, 946. 
ftalim, nie jest wyjątkowy, gdyż ST zna takie przykłady (Sdz 1,2-35; 1 Krn 2-9; $12,25-38 ; 27,16-22)^{49}$.

Wypada jednak postawić pytanie o powód, dla którego autor wybrał imię „Manasses”, a nie „Efraim”? Najprostsza odpowiedź wskazywałaby na fakt pierworództwa Manassesa. Jednakże w świetle danych ST, a zwłaszcza Rdz 48,13-20, Efraim, pomimo tego, iż był młodszy, odgrywał ważniejszą rolę niż Manasses. W $\mathrm{Rdz} 48,13-20$, patriarcha Jakub-Izrael przez nałożenie prawicy udzielił swego specjalnego błogosławieństwa Efraimowi, młodszemu synowi Józefa. W efekcie, Efraim otrzymał pierwszeństwo przed Manassesem, a co się $\mathrm{z}$ tym wiązało większe znaczenie polityczne, gospodarcze i religijne. $\mathrm{W}$ istocie większość list starotestamentowych wzmiankujących obu synów Józefa wymienia Efraima przed Manassesem ${ }^{50}$. Także archeologiczne badania powierzchniowe potwierdzają nadrzędną rolę Efraima ${ }^{51}$. Z drugiej strony, literatura prorocka ST, zwłaszcza Ozeasz $(4,17 ; 5,3 ; 6,10 ; 7,8 ; 8,11 ; 9,13 ; 11,12 ; 12,1 ; 13,1)$, są bardzo krytyczne w stosunku do Efraima. Bez wątpienia najpoważniejszym zarzutem wobec Efraima jest grzech bałwochwalstwa: Efraim związał się z boż-

49 Dla E.W. Hengstenberga, Revelation, I, 303, odwrócona kolejność, wpierw młodszy Neftali i następnie starszy Dan (w tekście Neftali - Manasses), jest dowodem na świadome zastąpienie imienia Dan przez Manasses, gdyż Manasses występuje tutaj jako podporządkowany imieniu Neftali. Co ciekawe, H.B. Swete (The Apocalypse of St. John [London: Macmillan 1911] 98) twierdzi, że to Lewi zastąpił brakującego Dana.

50 Spośród 17 list wzmiankujących synów Józefa, w 13 wykazach Efraim występuje jako pierwszy, i tylko w 4 przypadkach pierwszym jest Manasses (Lb 26,5-50; 34,19-28; Ez 48,1-28; 1 Krn 2-9). Listy z pierwszeństwem Efraima to Lb 1,5-16; 1,20-46; 2,3-31; 7,12-78; 10,14-27; 13,4-15; Joz 13-19; 21,4-7; 21,9-38; 1 Krn 6,39-48; 6,50-66; 12,25-38; 27,16-22. Zob. także Pwt 33,6-25 (w. 17).

51 Według badań powierzchniowych w okresie Żelaza I na terenach Manassesa zidentyfikowano 96 osad, a na terenie Efraima 115, podczas gdy w okresie monarchii (Żelazo II) poświadczono istnienie 140 osiedli w Manassesie i 190 w Efraimie. Zob. I. Finkelstein, The Land of Ephraim Survey 1980-1987: Preliminary Report, Tel Aviv 15-16 (1988-1989) 178-179. Różnica w wielkości obu plemion jest także widoczna na podstawie danych biblijnych. Pwt 33,17 stwierdza: Oto dziesiątki tysięcy Efraima, oto tysiące Manassesa. Księga Liczb 1,32-35 oraz 2,18-21 podaje, iż liczba synów Efraima powyżej 20 roku życia i zdolnych do walki wynosiłą 40 500, podczas gdy w Manassesie 32 200. Co ciekawe, według Lb 26,28-37, liczby te rozkładały się odwrotnie: 52700 w Manassesie oraz 32500 w Efraimie. Bardzo możliwe, że znaczenie pokolenia Efraima związane jest z lokalizacją na jego terytorium ważnego sanktuarium w Szilo. Z Efraima pochodził Jozue (Joz 19,49-50; 24,49-30) czy prorok Samuel (1 Sm 1,1). Po podziale monarchii, część północną nazywano „Efraim”. Wymienianie młodszego Efraima przed starszym Manassesem miało także usprawiedliwiać wybór Salomona na króla po śmierci Dawida w miejsce jego starszego brata Adoniasza, prawowitego następcy. Zob. I. Jaruzelska, Dwanaście plemion Izraela. Biblia a historia, RBL 53/3-4 (2000) 142. 
kami $(\mathrm{Oz} 4,17)$. W istocie jeden z pierwszych grzechów idolatrii opisanych na kartach ST dokonał się za sprawą Miki, Efraimity (Sdz 17,1-13). Czyn Miki jest bardzo negatywnie oceniony w dziele Pseudo-Filona, $L A B$ 44, datowanym na I w. po Chr.: karą dla Miki i jego matki miała być okrutna śmierć w męczarniach $(44,9)$. Ten negatywny obraz Efraima, zaczerpnięty ze ST i wciąż żywy w okresie powstawania NT, mógł być decydującym czynnikiem w pominięciu jego imienia w liście Janowej ${ }^{52}$.

W Liście Barnaby 14,4-6 opisana jest scena, w której Jakub-Izrael błogosławi Manassesa i Efraima. W interpretacji autora tegoż listu dwaj bracia reprezentują dwa przyszłe typy ludzi. Efraim, jako młodszy, otrzymuje błogosławieństwo i przymierze, podczas gdy starszy Manasses jest tego błogosławieństwa i przymierza pozbawiony. Chrześcijański autor listu sugeruje, że młodszy Efraim symbolizuje chrześcijan, podczas gdy starszy Manasses obrazuje wyznawców judaizmu. Jeśli to samo symboliczne rozumienie plemion Efraima i Manassesa było udziałem autora $\mathrm{Ap}^{53}$, wówczas listę pokoleń należałoby widzieć, jako wykaz plemion żydowskich (judaistycznych), z których wykluczony jest Efraim, reprezentant chrześcijan. Interpretacja zakładająca, że 144000 opieczętowanych z Ap 7,4 należy identyfikować z wyznawcami judaizmu jest jednak problematyczna i ostatecznie nieprawdopodobna.

M. Wojciechowski zwraca uwagę na fakt, że miasto Samaria należało do plemienia Manassesa. Autor Ap, wspominając Manassesa w tak niezwykłym miejscu, tj. przed jego ojcem Józefem, czyni aluzję do nawrócenia Samarytan (zob. J 4,39-42; Dz 8,4-24). Lista ma zatem charakter mesjański, gdyż odzwierciedla nowy porządek zbawienia ${ }^{54}$.

Podobnie jak wcześniejsi komentatorzy, R. Bauckham twierdzi, że Józef może być identyfikowany w tej liście z Efraimem ${ }^{55}$. W Ez 37,16 plemiona północne symbolizowane są przez kawałek drewna z napisem Józef, drewno Efraima, i cały dom Izraela. Nieco dalej, w. 19, tekst ponownie wiąże Józefa $\mathrm{z}$ Efraimem: drewno Józefa, które jest $w$ ręce Efraima, i plemion Izraela jego towarzyszy. W efekcie, jak wyjaśnia Bauckham: „the name of Joseph has been

52 E.W. Hengstenberg, Revelation, I, 300-301; G.B. Gray, The List, 225 oraz 235-236; C.R. Smith, The New Israel, 115; id., The Tribes, 218; R.E. Winkle, Another Look, 57.

53 Taką możliwość, jako jedną z wielu możliwych interpretacji, zakłada D.E. Aune, Revelation 6-16, 463.

54 M. Wojciechowski, Church, 34.

55 R. Bauckahm, Christian War Scroll, 24; id., Climax, 221-222. Zob. H. Grotius, Annotationes, VIII, 304 („ex tribu Iosephi duodecim millia, id est, ex tribu Ephraimi”); D.E. Aune, Revelation 6-16, 464 („In Rev 7:8 it is possible that by the tribe of Joseph, the author may have actually meant Ephraim"). 
glossed with phrases referring to Ephraim, in such a way that the reader could think that 'Joseph' is here being used as a name for the tribe of Ephraim" ${ }^{\text {". Po- }}$ dobny precedens występuje w liście dwunastu plemion w Lb 13,4-16. Wykaz podaje wpierw plemię Efraima (w. 8), a następnie plemię Józefa z dopowiedzeniem, że idzie tutaj o plemię Manassesa (w. 11). W istocie, w listach ST bardzo często występuje Beniamin wraz z Manassesem i Efraimem ${ }^{57}$. Sam R. Bauckham nie jest do końca przekonany o prawdziwości swej interpretacji i określa ją jako prawdopodobną.

S. Goranson sugerował, że brak Efraima wynika z identyfikacji tegoż plemienia $\mathrm{z}$ faryzeuszami, którzy w zamierzeniu autora Ap są wykluczeni z grona 144000 opieczętowanych ${ }^{58}$. Hipoteza ta odwołuje się do qumrańskiego peszeru do księgi proroka Nahuma (4Q169), gdzie autor interpretuje Niniwę z Na 3,1 jako miasto Efraima zarządzane przez tych, którzy szukają łatwych rzeczy (החלקות דורשי), a którzy postępują drogą podstępu i kłamstwa (II, 2 oraz II, 8). Wśród badaczy zwojów qumrańskich panuje jednomyślne przekonanie, iż określenie החלקות דורשי odnosi się do faryzeuszy i jego pejoratywny wydźwięk

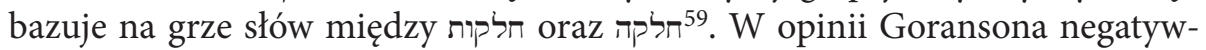
ne rozumienie Efraima byłoby udziałem nie tylko wspólnoty qumrańskiej, ale także autora Apokalipsy, który również identyfikował Efraima $\mathrm{z}$ faryzeuszami i $z$ tego powodu świadomie pominął to imię w 7,5-8 ${ }^{60}$. Trzeba jednak zauważyć, że chrześcijanie, włączając w to samego Pawła (Dz 23,6; Flp 3,5), wywodzili się także spośród faryzeuszy $(\mathrm{Dz} 15,15)$. Fakt ten poważnie podważa tezę Goransona, który brak Efraima w Ap 7,5-8 widzi w identyfikacji tego plemie-

\footnotetext{
56 R. Bauckahm, Christian War Scroll, 24.

57 Por. Lb 1,5-16; 1,20-46; 2,3-31; 7,12-78; 10,14-27; 13,4-15; 26,5-50; 34,19-28; Joz
} $13-19 ; 21,4-7 ; 21,9-38 ; 1$ Krn 2-9; 6,39-48; 6,50-66; 12,25-38; 27,16-22.

58 S. Goranson, The Exclusion of Ephraim in Rev. 7:4-8, DSD 2 (1995) 80-85.

59 Por. A. I. Baumgarten, Seekers after Smooth Things, Encyclopedia of the Dead Sea Scrolls [= EDSS] (red. L.H. Schiffman - J.C. VanderKam) (Oxford: Oxford University Press 2000) II, 858. Zob. także J. Amoussine, Éphraïm et Manassé dans le Péshèr de Nahum (4QpNahum), RevQ (1963) 389-396; D. Flusser, Pharisaer, Sadduzaer und Essener im Pescher Nahum, w: Qumran (red. K.E. Grozinger - N. Ilg - H. Lichtenberger et al.) (WdF 410; Darmstadt: Wissenschaftliche Buchgesellschaft 1981) 121-166; L.H. Schiffman, Pharisees and Sadducees in Pesher Nahum, w: Minhah le-Nahum. Biblical and Other Studies Presented to Nahum M. Sarna in Honour of His Seventieth Birthday (ed. M. Z. Brettler - M. Fishbane) (JSOT.S 154; Sheffield: Academic Press 1993) 272-290.

60 S. Goranson (The Exclusion, 85) podsumowywuje: „Rev. 7:4-8 conspicuously excluded Ephraim, and by so doing, the Essene-influenced author polemically asserted that Pharisees were not among those predestined elect who were to be sealed in advance of their resurrection". 
nia $\mathrm{z}$ faryzeuszami. Ponadto symboliczne nazewnictwo obecne we wspólnocie qumrańskiej nie musi być automatycznie obecne we wspólnocie chrześcijańskiej. Również sam Goranson podkreśla, że w literaturze rabinackiej znajdujemy bardzo pozytywny obraz Efraima jako plemienia, z którego miał pochodzić Mesjasz, prekursor Mesjasza Dawidowego ${ }^{61}$.

$\mathrm{Z}$ mojej strony chciałbym zwrócić uwagę na poświadczoną w literaturze rabinackiej tradycję o nieposłuszeństwie Efraimitów w ich przedwczesnym opuszczeniu Egiptu, które spotkało się z karą w postaci fizycznego wyniszczenia tego plemienia przez Filistynów ${ }^{62}$. Jeśli przyjąć, że tradycje o nieposłuszeństwie i wytraceniu Efraimitów sięgają I w. po Chr. - co zważając na charakter tych tekstów (np. Targumy) jest bardzo prawdopodobne, ten negatywny obraz Efraima zbiega się czasowo z negatywnymi konotacjami związanymi z imieniem „Efraim” obecnymi w pismach qumrańskich. W innych tekstach qumrańskich, termin Efraim ma nieco szerszy zakres znaczeniowy i określa nie tylko faryzeuszy, ale grupę z zasady wrogo nastawioną do przedstawicieli wspólnoty qumrańskiej ${ }^{63}$. W kontekście dyskusji nad Ap 7,4, warto zauważyć, że autor peszeru 4Q169, jak i autorzy innych zwojów qumrańskich, określają swoją wspólnotę

61 Dokładne omówienie tekstów związanych z postacią Mesjasza z plemienia Efraima, jak i wcześniejszą bibliografię dotyczącą tej postaci, dostarcza D.C. Mitchell, The Fourth Deliverer: A Josephite Messiah in 4QTestimonia, Bib. 86 (2005) 545-553; id., Rabbi Dosa and the Rabbis Differ: Messiah ben Joseph in the Babylonian Talmud, Review of Rabbinic Judaism 8 (2005) 77-90; id., Firstborn Shor and Rem: A Sacrificial Josephite Messiah in 1 Enoch 90.37-38 and Deuteronomy 33.17, JSPE 15 (2006) 211-228; id., Messiah bar Ephraim in the Targums, Aramaic Studies 4 (2006) 221-241; id., Messiah ben Joseph: A Sacrifice of Atonement for Israel, Review of Rabbinic Judaism 10 (2007) 77-94; id., A Dying and Rising Josephite Messiah in 4Q372, JSEP 18 (2009) 181-205.

62 Teksty mówiące o przedwczesnym (o 30 lat) wymarszu Efraimitów i ich militarnej klęsce w walce z Filistynami: Tg. Wj 13,17 (Tg. Ps.-J., Frg. Tg.), Tg. Ez 37, Tg. Ps 78,9, Tg. 1 Krn 7,20-21, b. Sanh. 92b. Zob. także Mek. Wj 13,17, Ex Rab. 20,1, Sg Rab. 2,7, Priqe R. El. 48, Tg. Ps.-J. Rdz 50,25. Faktem jest, iż Bar Kochba był identyfikowany z Mesjaszem z plemienia Efraima. Niektórzy autorzy uważają, że klęska jego powstania była katalizatorem dla powstania tradycji, poświadczonej przez wiele tekstów rabinackich, która interpretuje wizje z Ez 37 jako zmartwychwstanie Efraimitów, a tym samym także ich wodza, Bar Kochby. Zob. B.W.R. Pearson, Dry Bones in the Judean Desert: The Messiah of Ephraim, Ezekiel 37, and the Post-Revolutionary Followers of Bar Kokhba, JSJ 29 (1998) 192-201.

63 W 4Q171 (peszer do Ps 37,15-16) autor identyfikuje wrogów Mistrza Sprawiedliwości z przewrotnym Efraimem i Manassesem. W CD VII 9-14 Efraim odstępuje od Judy, przy czym termin Juda oznacza tutaj członków wspólnoty qumrańskiej. W CD XIII-XIV ci, którzy zbaczają z drogi sprawiedliwości, przyrównani są do Efraima, który odstąpił od Judy. H. Eshel, Ephraim and Manassesh, EDSS, I, 253-254. 
prawdziwym Izraelem ${ }^{64}$ oraz domem Judy ${ }^{65}$. Również dla autora Apokalipsy, Kościół jest prawdziwym Izraelem, a każdy, kto odcina się od niego, może być w przenośni przyrównany do Efraima odcinającego się od zwycięskiego Lwa Judy i nowej Jerozolimy. Brak plemienia Efraima w liście plemion w Ap 7,4-8, przy jednoczesnej obecności w niej Manassesa, byłaby zatem motywowana generalną negatywną oceną Efraimitów na kartach ST (por. Sdz 17,1-13; Ozeasz), a w czasach NT poświadczoną zarówno w zwojach qumrańskich, jak i w targumicznej i rabinackiej tradycji o przedwczesnym exodusie. Powracając zatem do tezy Goransona, można stwierdzić, że identyfikacja Efraima z faryzeuszami, jako zamysł autora Apokalipsy stojący za wykluczeniem tegoż plemienia z listy w 7,5-8, nie jest konieczna w świetle bardziej prawdopodobnej interpretacji, która widzi pominięcie Efraima jako skutek identyfikacji tegoż plemienia z rebelią przeciw Bogu (idolatria) oraz Judzie i Jeruzalem (secesja).

\section{Nieobecność Dana}

Starsze komentarze (Gomarus, Hartwig, Bleek, Züllig, Spitta) sugerowały błąd kopisty, który w miejsce $\triangle \mathrm{AN}$ zapisał skrót MAN. Skrót ten za sprawą następnych kopistów miałby przybrać pełną formę MANA $\Sigma \Sigma \mathrm{H}^{66}$. Umieszczenie Manassesa po Nefatalim jest logiczne, gdyż obaj są synami jednej matki, Bilhy, niewolnicy Racheli. R. H. Charles odrzuca jednak takie wyjaśnienie stwierdzając: „But such abbreviations are highly improbable, and very seldom occur in Uncial MSS. and the corruption of $\Delta \dot{\alpha} v$ into Móv is unlikely in the case of such a well-known list as that of the twelve tribes" ${ }^{\prime 7}$.

64 L.H. Schiffmann (Israel, EDSS, I, 389) stwierdza: „They [sectarians] understood the history of Israel in biblical times as essentially a period of religious and moral decline leading to the destruction of the First Temple. This process, described in theological terms in the Admonition at the beginning of the Damascus Document (CD I-VIII), meant that God's covenant with Israel was transferred to the righteous remnant - the members of the Qumran sect and those who would join them in the End of Days. In effect, then, the sectarians saw themselves as the true Israel, the people of God".

65 Zob. CD IV 11; 1QpHab VIII 1; 4Q171 1-10 II 14; 4Q174 4 4; 1-3 II 1. Por. D.R. Schwartz, To Join Oneself to the House of Judah (Damascus Document IV, 11), RevQ 10 (1981) 440; R. Ratzlaff, House of Judah, EDSS, I, 439.

66 Rozwiązanie takie proponuje także G. V. Sanderson, In Defence of Dan, Scripture 3-4 (1948) 114-115. Lista pozostałych autorów za R.H. Charles, Revelation, I, 208.

67 R. H. Charles, Revelation, I, 208. W istocie, jak twierdzi Beale, Revelation, 421, nie istnieje żaden ms, który potwierdzałby istnienie skrótu MAN. 
Inni komentatorzy (Grotius, Ewald, De Wette, Düsterdieck) twierdzili, że Dan nie znalazł się na liście, gdyż wymart jako plemię ${ }^{68}$. Takie stwierdzenie nie znajduje jednak podstaw w historii Izraela, gdyż wszystkie plemiona północne dzieliły los wygnańców; każde z nich zatem winno być określone jako wymarłe i pozbawione miejsca na liście. Józef Flawiusz stwierdza, że w czasach sobie współczesnych, a więc I w. po Chr., wciąż istniały plemiona północne przebywające na wygnaniu w Mezopotamii ${ }^{69}$. W istocie nie jest ważne, czy plemiona te rzeczywiście istniały w czasach powstania Ap, ale czy wierzono w tym okresie historycznym, że te pokolenia istnieją. W świetle tekstu Józefa Flawiusza, odpowiedź na oba pytania wydaje się twierdząca.

W. Bousset, a za nim wielu późniejszych komentatorów, odwołał się do interpretacji obecnej w starożytnej egzegezie chrześcijańskiej, która usunięcie Danitów z listy w Ap 7,5-8 upatrywała w pochodzeniu Antychrysta z rodu Dana $^{70}$. Najwcześniejszym świadectwem tej tradycji jest tekst Ireneusza z Lyonu (†202), Przeciw Herezjom V, 30,2, interpretujący Jr 8,16 jako proroctwo o przyszłym nadejściu Antychrysta z plemienia Dana. Ireneusz wyraźnie stwierdza, że pokolenie Dana nie zostało wymienione w Apokalipsie z tego właśnie powodu: Et propter hoc non annumeratur tribus haec in Apocalypsi cum his quae salvantur $^{71}$. Jednym $\mathrm{z}$ najbardziej wymownych świadectw tejże tradycji jest zdanie Hipolita Rzymskiego (†235) z traktatu O Chrystusie i Antychryście 14:

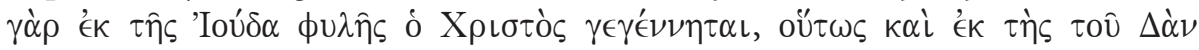

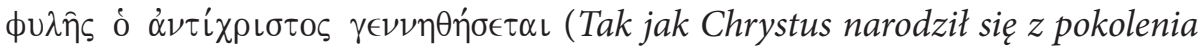

68 Nazwiska autorów za R.H. Charles, Revelation, I, 208.

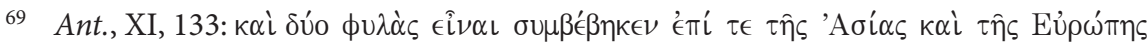

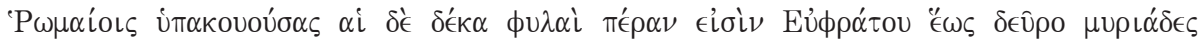

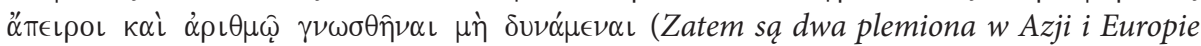
poddane Rzymianom, podczas gdy dziesięć plemion jest za Eufratem aż dotąd, i sq one $w$ niezliczonym mnóstwie, i nie można ich określić w liczbie).

70 W. Bousset, Die Offenbarung Johannis (KEK 16; Göttingen: Vandenhoeck \& Ruprecht 1859. $\left.{ }^{5} 1896\right)$ 282; id., Der Antichrist in der Überlieferung des Judentums, des neuen Testaments und der alten Kirche. Ein Beitrag zur Auslegung der Apocalypse (Göttingen: Vandenhoeck und Ruprecht 1895) 112-115. Listy starożytnych autorów i ich dzieł w Bousset, Der Antichrist, 113; R.H. Charles, Revelation, I, 209. By zacytować jedynie Andrzeja z Ce-

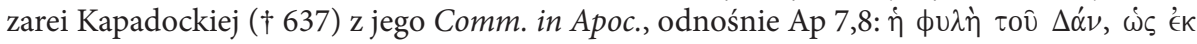

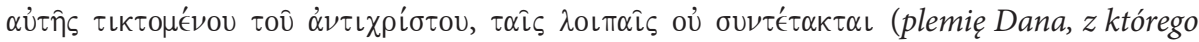
zrodzony jest Antychryst, do pozostałych [plemion] nie jest dopisane) (PG 106, kol. 281). Ko-

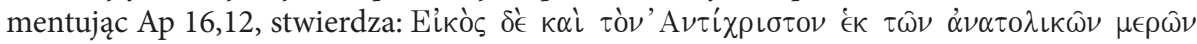

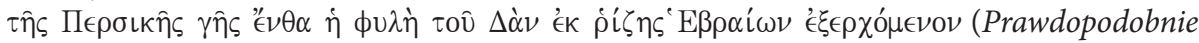
Antychryst przyjdzie ze wschodnich części krainy Persji, gdzie jest plemię Dana, pochodzace z Hebrajczyków) (PG 106, kol. 368).

71 PG 7b, kol. 1205. 
Judy, tak Antychryst będzie zrodzony z pokolenia Dana) $)^{72}$. Bousset sugeruje, że tradycja o pochodzeniu Antychrysta z plemienia Dana może być przedchrześcijańska, jako że jej źródłem może być Testament Dana 5-6, gdzie księciem Dana jest Szatan $(5,6)^{73}$. Warto jednak zauważyć, że w Testamencie Dwunastu Patriarchów powiązanie z Beliarem (vel Szatanem) nie ogranicza się jedynie do Danitów, ale jest właściwe także synom Issachara (Testament Issachara 6,1). Mimo że niektórzy chcieliby się spierać o to, czy tradycja o pochodzeniu Antychrysta z pokolenia Dana jest przedchrześcijańska, czy też jest dziełem samych chrześcijan, faktem jest, że tradycja ta nie jest explicite poświadczona przez żadne źródło żydowskie, a jej pierwszym świadkiem jest dzieło Ireneusza ${ }^{74}$. Współcześnie, autorzy z reguły odrzucają wpływ tej tradycji na Ap 7,5-8, uważając ją za zbyt późną, a więc chrześcijańską ${ }^{75}$. R. Bauckham zauważa, że dla autora Ap Antychrystem był Rzym, a nie Dan, dlatego użycie tradycji o Antychryście z pokolenia Dana (przyjmując nawet jej istnienie w czasach NT) jest nieprawdopodobne ${ }^{76}$. Stwierdzenie to spotkało się ze słuszną polemiką ze strony C. R. Smitha, którzy zauważył, że termin „Antychryst” nie pojawia się w Ap, sam Rzym nazwany jest „bestią”, a koncepcja Antychrysta w Ap (nawet bez użycia tego terminu) odnosi się nie tylko do Rzymu, ale także do innych podmiotów, np. członków synagogi szatana z Ap 2,977. W istocie, szerokie spectrum eschatologicznych wrogów Chrystusa w Ap (smok-wąż, pierwsza bestia,

72 Za R.H. Charles, Revelation, I, 209.

73 Bousset, Der Antichrist, 114-115.

74 Chrześcijańskie pisma apokaliptyczne łączące Antychrysta z Danem wymienia K. Berger, Die griechische Daniel-Diegese. Eine altkirchliche Apokalypse (StPB 27; Leiden: Brill 1976) 101. Przykłady średniowiecznych autorów i ich dzieł podaje R.K. Emmerson, Antichrist in the Middle Ages. A Study of Medieval Apocalypticism, Art., and Literature (Seattle, WA: University of Washington Press 1981.

75 Najbardziej rozbudowaną argumentację za odrzuceniem tej interpretacji w Ap 7,5-8 prezentuje B. Cangemi Trolla, Lassenza della tribù di Dan nell'Apocalisse canonica (7,5-8) alla luce delle tradizioni sul patriarca Dan e sui suoi discendenti w: Cristianesimi nell'antichità: fonti, istituzioni, ideologie a confronto (red. A. D’Anna - C. Zamagni) (Spudasmata 117; Hildesheim - Zürich - New York, NY: Georg Olms 2007) 39-58. Można z dużą dozą prawdopodobieństwa przyjąć, iż tradycja o Nie-Mesjaszu rodziła się wśród chrześcijan wraz z odrzuceniem mesjańskości Jezusa z Nazaretu przez niektórych Żydów oraz wciąż żywym żydowskim oczekiwaniem na innego Mesjasza, które swój wyraz znalazło m.in. w obwołaniu Mesjaszem Bar Kochby, który w oczach chrześcijan był oczywistym Anty-Mesjaszem. Każdy zatem żydowski Mesjasz, inny niż Jezus, widziany był przez chrześcijan jako Anty-Chrystus. Przekonywujące studium o rozwoju idei Antychrysta: C.E. Hill, Antichrist from the Tribe of Dan, JTS 46 (1995) 99-117. Zob. także przypis 89.

76 R. Bauckham, The List, 101; id., The Climax of Prophecy, 223.

77 C.R. Smith, The Tribes, 217. 
druga bestia-pseudoprorok) uwiarygodnia możliwość identyfikacji Dana jako kolejnego wroga Chrystusa.

Sam R. Bauckham twierdzi z kolei, że motywem braku Dana jest obecność plemienia Manassesa; aby utrzymać całościową liczbę dwunastu plemion, ten pierwszy musiał zostać pominięty ${ }^{78}$. Taka sugestia nie dotyka jednak istoty problemu, która zwiera się w odpowiedzi na pytanie, dlaczego pominięty został właśnie Dan, a nie inne plemię.

Część współczesnych komentatorów upatruje braku plemienia Dana w Janowej liście dwunastu plemion w negatywnym przedstawieniu tego pokolenia na kartach ST. Idzie tutaj o teksty: Rdz 49,17 ([Dan] będzie jak wąż na drodze, jak żmija jadowita na ścieżce, kasająca pęciny konia, z którego jeździec spada na wznak); Sdz 18,30 (Danici postawili sobie rzeźbiony posążek) oraz Jr 8,16 (Od Dan daje się slyszeć parskanie ich koni; na odgłos rżenia ich rumaków drży cała ziemia. Przybywaja, by pochłonać kraj i jego zasoby, miasto i jego mieszkańców). Zła sława Danitów poświadczona jest także w starożytnej żydowskiej literaturze pozabiblijnej. Przykładem może być Vitae Prophetarum, utwór datowany między II w. przed Chr. (pierwsze stratum żydowskie) a II w. po Chr. (interpolacje chrześcijańskie), gdzie prorok Ezechiel wypowiada sąd nad plemionami Dana i Gada za świętokradzki czyn prześladowania tych, którzy przestrzegali Tory w Babilonii $(3,16)$. Ostatecznie, niezidentyfikowana osoba z pokolenia Dana i Gada zabija Ezechiela $(3,20)$, mszcząc się za wytykanie im bałwochwalstwa $(3,2)$. W Testamentach Dwunastu Patriarchów Dan jest tym, który wśród swych braci pałał największą niechęcią do Józefa ${ }^{79}$. To on rozweselił się po śmierci Józefa (T. Dan 1,4) oraz z faktu sprzedania go do Egiptu $(1,5)$; on także wymyślił kłamstwo odnośnie do losu Józefa i zaplanował cały podstęp z pokrwawioną szatą Józefa, by zataić prawdę przed Jakubem (T. Zabulon 4,7-13). Sam Dan wyznaje, że jeden z duchów Beliara działał w nim, zachęcając go do zabicia Józefa (T. Dan 1,7). W dziele Józef i Asenet, datowanym między I w. przed Chr. a II w. po Chr., Dan i Gad są tymi, którzy organizują zasadzkę i czyhają na życie Asenet $(24-27)^{80}$.

Padła także sugestia, że brak pokolenia Dana w liście dwunastu pokoleń jest wynikiem apostazji tego plemienia. Idea apostazji Dana wydaje się późniejszym, tj. postbiblijnym rozwinięciem tradycji zawartych w Rdz 49,17; Sdz 18,30 oraz Jr 8,16. Testament Dana 5,4-8 zapowiada apostazję całego poko-

78 R. Bauckham, „List”, 113.

79 Podobna niechęć do Józefa charakteryzuje także Gada (T. Gad 1) oraz Symeona (T. Symeon 2,6-7).

80 Za B. Cangemi Trolla, Lassenza della tribù di Dan, 53. 
lenia. Z drugiej jednak strony, dalszy ciąg tej wyroczni mówi o udziale tego plemienia w eschatologicznym zbawieniu Izraela $(5,9-13)^{81}$.

Z ideą apostazji związany jest grzech idolatrii, którego miało dopuścić się plemię Dana. Idolatria Dana poświadczona jest zarówno przez teksty biblijne (Sdz 18,30, $1 \mathrm{Krl}$ 12,28-30), jak i żydowską literaturę pozabiblijną ${ }^{82}$. Mimo że popadnięcie w grzech idolatrii jest właściwe wszystkim plemionom północnym (por. $1 \mathrm{Krl}$ 12,25-33), Dan, przez usytuowanie w nim jednego z dwóch głównych separatystycznych sanktuariów (Dan i Betel), odgrywałby symboliczną rolę protagonisty. Echa tego wydarzenia znajdujemy w $2 \mathrm{Krl}$ 10,29; Am 8,14; Tb 1,5 oraz starożytnej żydowskiej literaturze pozabiblijnej ${ }^{83}$. Daje dużo do myślenia idealistyczna wizja podziału terytorium w Ez 48,1-28, gdzie Dan znajduje się na samej północy, w miejscu najbardziej odległym od nowej świątyni ${ }^{84}$.

Jeśli rozumieć brak obcowania z kobietami w Ap 14,4, jako uniknięcie idolatrii ${ }^{85}$, wówczas Dan, który dopuścił się cudzołóstwa - idolatrii, nie może mieć miejsca pośród 144000 opieczętowanych. W istocie problem idolatrii przewija się jako jeden z głównych motywów Ap (zob. 2,14.20; 9,20-21; 13,12-15;

81 Bauckham, „List”, 101; R. Aune, Revelation 6-16, 462.

82 Tg. Ps.-J. Wj 17,8 (Amalekita przybył z ziemi południowej... i prowadził wojnę z Izraelem $w$ Refidim. I wzią i wycią mężów domu Dona, ponieważ obłok nie przyjmowat ich ze względu na bałwochwalstwo, które praktykowali); Tg. Ps.-J. Lb 11,1 ([Pan] zniszczył niektórych spośród przewrotnych, którzy byli na obrzeżach obozu, tych z domu Dana z którymi był bożek); 22,41; Tg. Ps.-J. Pwt 25,18 (każdy kto myślat o oddaleniu się od Memra został stracony: mężowie z plemienia domu Dana w których ręku było dziwne batwochwalstwo. $\mathrm{Ob}$ łok odrzucit ich i dom Amaleka zastawit na nich zasadzkę i pozbawił ich przyrodzenia); Tg. Pnp 2,15; Tg. Jr 8,16; Tg. Am 8,14; Rdz Rabba 43,2; Lb Rabba 2,10; Midrasz do Ps 101,2; b. Sanhedrin 96a; 103b; b. Shabbat 67b; Pesiqta Rabbati 11,3; 12,13; 46,3; Sifre Pwt 357 do Pwt 34,1; Pesiqta deRab Kahana 3,12 (27b). Pseudo-Filon, LAB 25,9, zamieszcza wyznanie synów Dana, iż nauczyli się oni sztuki magicznej od Amorytów. Beale (Revelation, 421) zwraca uwagę na Tg. Ps.-J. Lb 22,41-23,1, który mówi o pokoleniu Dana, które sprawowało bałwochwalczy kult i obozowało na samym końcu obozu poza zasięgiem obłoku Chwały. Nieco dalej $(23,21.23)$ czytamy, że w domu Jakuba i w domu Izraela nie ma tych, którzy czczą fałszywych bogów. Idolatria była zatem równoznaczna z wykluczeniem spośród plemion Izraela.

832 Baruch 62,1-3; Vitae prophetarum 19,2; 22,2; Józef Flawiusz, Ant., VIII, 225-228. Zob. dogłębne studium dotyczące kultycznych tradycji związanych z Dan: J.S. Bray, Sacred Dan. Religious Tradition and Cultic Practice in Judges 17-18 (Library of Hebrew Bible / Old Testament Studies 449; London-New York, NY: T. \& T. Clark 2006).

84 Na szczegół ten zwraca uwagę Hengstenberg, Revelation, I, 300-301.

85 Taka interpretacja wydaje się najwłaściwsza w kontekście Ap. Zob. E. Norelli, Une prophètesse contestée: Jézabel (Apc 2,20-23), BCPE 4-5 (1998) 29-40, esp. 34. 
$14,9 ; 19,10.20 ; 21,8 ; 22,9.15)$. Ocena idolatrii jest jednoznaczna: jedynie samemu Bogu należy się cześć $(19,10 ; 22,9)$; bałwochwalcy nie mogą zamieszkiwać w nowym Jeruzalem $(22,15)$; ich miejsce jest w jeziorze gorejącym ogniem i siar$k q(21,8)$. Nie ulega wątpliwości, iż powiązanie Dana z kultem bałwochwalczym mogło wpłynąć na usunięcie tego pokolenia $\mathrm{z}$ listy opieczętowanych w Ap 7,5-8 $8^{86}$.

Współcześni autorzy podkreślają jednak, że na niekorzyść powyższych trzech wyjaśnień (zła sława, apostazja, idolatria) przemawia fakt, iż listy dwunastu plemion znajdujące się w żydowskiej literaturze pozabiblijnej (chociażby w zwojach qumrańskich) zawierają Dana. Widać zatem, że negatywny obraz Dana nie był na tyle silnym motywem, aby wykluczyć to plemię z list dwunastu plemion w czasach, w których powstawał NT ${ }^{87}$. Co ciekawe, w Midrasz Rabba do $\operatorname{Rdz}(97,9)$ znajduje się tekst mówiący o matce Mesjasza pochodzącej z plemienia Dana. Rabbi Hama b. Rabbi Hanina (III w. po Chr.), komentując błogosławieństwo Jakuba dla Judy w Rdz 49,9, stwierdził: To odnosi się do Mesjasza, syna Dawida, który powstanie $z$ dwóch plemion: jego ojciec $z$ Judy, a jego matka $z$ Dana $^{88}$. To samo stwierdzenie znajduje się w Yalkut Shimoni do Rdz 49,989.

Warto zwrócić jeszcze uwagę na dwa interesujące przypadki zawarte na kartach ST. W 1 Krn 2-9 w genealogiach potomków Jakuba nie wymienia się

86 Taka jest również konkluzja najnowszego studium: Cangemi Trolla, Lassenza della tribù di Dan”, 57: „Pertanto, mi sembra molto più plausibile spiegare tale omissione (intenzionale) a partire dalla reputazione particolarmente negativa ed idolatra della tribù di Dan, vista la grande importanza che riveste l'esortazione contro il culto degli idoli nell'Apocalisse".

87 Jedynym wyjątkiem jest Pseudo-Filon, $L A B$ 25,4, który pomija Dana i Neftalego. Powodem opuszczenia jest jednak błędna transmisja tekstu. Zob. D.E. Aune, Revelation 6-16, 462; R.E. Winkle, Another Look, 60-61.

88 D.N. Freedman - M. Simon, Midrash Rabba. Genesis (London: Soncino 1939) II, 906.

89 Za R. Bauckham, Christian War Scroll, 36, przypis 24. Zarówno Midrasz Rabba do Rdz, a zwłaszcza Yalqut Shimoni, są późnymi tekstami, kolejno V-VII w. oraz XII w.; ich wartość argumentacyjna zatem jest bardzo słaba. W opinii C.E. Hilla (Antichrist, 112-113) midrasz ten jest egzegetycznym dowodem na istnienie $\dot{z} y d o w s k i e j$ idei o Mesjaszu pochodzącym z plemienia Dana. W sposób oczywisty takie twierdzenie musiało spotkać się z polemiką chrześcijańską: jedynym Mesjaszem jest Jezus Nazarejczyk z pokolenia Judy, a Mesjasz z pokolenia Dana, czy też każdy inny Mesjasz oczekiwany przez Żydów, jest Anty-Mesjaszem. Świadkami tejże polemiki byłyby dzieła Ireneusza czy też Hipolita, ale także 1

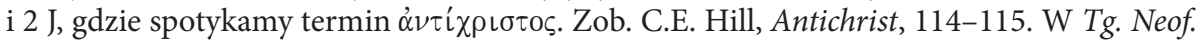
Rdz 49,17 czytamy: mesjasz, który powstanie z domu Dana; będzie on silny, wywyższony ponad wszystkie narody. Tekst wyjaśnia jednak, że idzie tutaj o Samsona bar Manoaha, jednego z sędziów ST (por. Sdz 13,2; zob. także Midrasz Rabba do Rdz, nr 98,13-14; do Lb, nr 10,5; $13,9)$. 
Dana. Fakt, że pominięty jest także Zabulon, każe być jednak ostrożnym w wyciąganiu daleko idących konkluzji. W tej samej sekcji jednakże, w liście miast ucieczki (6,50-66), przydziela się te miasta na terytorium Zabulona $(6,62)$, ale nie robi się tego z terytorium pokolenia Dana! W 6,39-49 w opisie przydziału miast dla lewitów brakuje Efraima oraz ponownie Dana! ${ }^{90}$ Bardzo możliwe, że pominięcie Dana jest odzwierciedleniem tradycji o bałwochwalstwie tegoż plemienia. Nacisk, jaki kładzie się w Ap na wykorzenienie idolatrii oraz na tożsamość nowego Izraela jako ludu kapłańskiego $(1,6 ; 5,10)$, pozwala interpretować nieobecność Dana w Ap 7,5-8, jako znak czystości wiary nowego Izraela, w której nie ma miejsca na bałwochwalstwo.

Przynajmniej trzech współczesnych autorów bazuje na przekonaniu, że na listę dwunastu plemion w Ap 7,5-8 należy patrzeć w świetle dwunastu apostołów Jezusa i konsekwentnie utożsamić Dana z Judaszem ${ }^{91}$. Według C. R. Smitha lista Janowa jest odzwierciedleniem nowego Izraela zbudowanego z dwunastu plemion Izraela na fundamencie dwunastu apostołów. Symbolizm taki odpowiada (1) liczbie 144000 opieczętowanych (12 x 12 x 1000), (2) wizji murów nowej Jerozolimy mających dwanaście bram $\mathrm{z}$ imionami plemion Izraela i zbudowanych na dwunastu warstwach fundamentu mających imiona apostołów (Ap 21,12-14) oraz (3) zapowiedzi Jezusa mówiącej o dwunastu apostołach mających sądzić dwanaście plemion Izraela (Mt 19,28; Łk 22,30) ${ }^{92}$. Konsekwentnie, zdrajca Judasz, należący do pierwotnej grupy dwunastu apostołów i któremu odpowiadałoby pokolenie Dana, zostaje zastąpiony przez Macieja (Dz 1,12-16), którego miałoby reprezentować pokolenie Manassesa.

Wyjaśnienie to jest przekonywające w świetle dwóch znanym nam faktów: (1) Dan już w ST był identyfikowany z idolatrią, a w czasach późniejszych, już w okresie powstania NT, z apostazją i Szatanem (Testament Dana 5,6). (2) Li-

90 Niektóre mss dodają jednak te dwa plemiona w w. 46, który w sposób widoczny był poddany pracy redakcyjnej polegającej na usunięciu jednego lub dwóch plemion. Odnośnie braku Dana zob. R.L. Braun, 1 Chronicles 1-9 and the Reconstruction of the History of Israel: Thoughts on the Use of Genealogical Data in the Chonicles in the Reconstruction of the History of Israel, w: The Chronicler as Historian (red. M. P. Graham, K. G. Hoglund, S. L. McKenzie) (JSOT.S 238; Sheffield: Sheffield Academic Press) 99, przypis 13: „A good case can be made that the omission is due to simple textual error. However, the tribe of Dan is also missing in 1 Chron. 6.46, $54[61,69]$, suggesting a tendential omission".

91 A. Farrer, Revelation, 108 („let Dan be the Judas of the Patriarchs [...]. St. John puts the names of the apostles round the city, pairing them with the tribes. We cannot suppose that Iscariot's name would stand there, any more than Dan's."); R.E. Winkle, Another Look, 61-66; C.R. Smith, The New Israel, 115-116.

92 O związku dwunastu apostołów z dwunastu plemionami zob. A. Feuillet, „Sąd dwunastu apostołów nad dwunastoma pokoleniami Izraela”, Communio 29 (2009) nr 1, 76-86. 
sta w Ap 7,4-8, a dokładnie liczba 144 000, jest związana z liczbą dwunastu apostołów, co wynika z występującej w NT asocjacji dwunastu plemion Izraela z dwunastu apostołami Jezusa (Mt 19,28; Łk 22,30; Ap 21,12-14). W świetle powyższych przesłanek, utożsamienie Judasza z Danem jest zrozumiałe. Szczególnie wymowne $\mathrm{w}$ tym kontekście jest Janowe przedstawienie Judasza jako narzędzia Szatana $(J 13,27)^{93}$.

R. E. Winkle sugerował, że związek między Judaszem a Danem może być widoczny w Dziejach Apostolskich. W opisie wyboru Macieja (Dz 1,15-26)

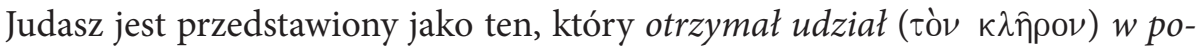
słudze apostołów (w. 17). Sprzeniewierzył się on jednak temu powołaniu, aby

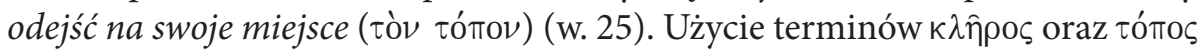
miałoby odzwierciedlać dzieje plemienia Dana, które nie było w stanie utrzymać swego dziedzictwa ( 'то६) $(18,3.10 .12)^{94}$.

Utożsamienie apostołów z izraelskimi plemionami nie jest właściwe jedynie współczesnym egzegetom. R. E. Winkle podaje szereg późniejszych chrześcijańskich tradycji, które utożsamiały Judasza z plemieniem Dana: syryjska Księga Jaskini Skarbów (IV w.) (Judasz miał pochodzić z plemienia Gada lub Dana), Prokop z Gazy (†528) w komentarzu do Rdz 49,16-18, etiopskie dzieło Walki Apostołów w rozdziale o genealogiach dwunastu apostołów (VI w.), Kronika Michała Syryjczyka, Salomon z Basry w Księdze Pszczoły (Judasz pochodził z pokolenia Gada, ale według opinii mniejszości był z pokolenia Dana) ${ }^{95}$.

93 Zob. A. Gagné, Caractérisation des figures de Satan et de Judas dans le IVe Évangile: stratégie narrative et déploiement des intrigues de conflit, Science et esprit 55 (2003) 263-284.

94 R.E. Winkle, Another Look, 63. Autor ten (ibid., 63, note 29) podkreśla także, że terminy $\mathrm{klh} /$ roj oraz $\kappa \lambda \eta \rho \nu \mathrm{\mu} \mu \mathrm{i} \alpha$ były używane zamiennie w odniesieniu do terytoriów plemiennych (Joz 19,1-2.39.47). Testament Dana 7,3 mówi o pozbawieniu Dana dziedzictwa. Testament Asera 7,6 przepowiada rozproszenie Gada i Dana, tak że nie będą znali swych ziem, plemion i języka.

95 R.E. Winkle, Another Look, 63-64. Od XIII w. istnieje już tylko tradycja o pochodzeniu Judasza z pokolenia Dana. Jako argument za identyfikacją Judasza z Danem, Winkle (ibid., 65-66) przywołuje również tradycje, które identyfikowały Dana z wężem; bazują one na Rdz 49,17, gdzie czytamy, że Dan będzie jak wąż na drodze, jak żmija jadowita na ścieżce. J. R. Harris („Did Judas Really Commit Suicide?”, AJT 4 [1900] 508) sugerował, że opis śmierci Judasza mówiący o jego przewróceniu się głowa do przodu, tj. padnięciu na

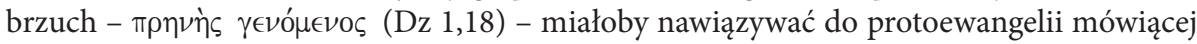
o czołganiu się węża na brzuchu (Rdz 3,14). Następnie F. H. Chase („In prēnēs genomenos

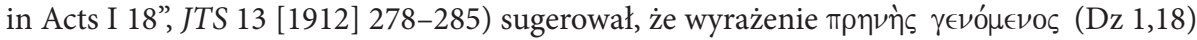
jest określeniem medycznym na opuchliznę. Śmierć Judasza opisana w Dz 1,18 byłaby zatem efektem jego opuchnięcia, pęknięcia i wypłynięcia jego wnętrzności. Późniejsze tradycje tak właśnie, jako opuchnięcie i pęknięcie, przedstawiają śmierć węża - np. gnostyckie Dzieje 
S. Pinès omawia także arabski tekst Kitāb al-'Inwan, który zawiera listę apostołów wraz z nazwami poszczególnych plemion, z których pochodzili. Autorem tekstu jest Agapius (arab. Mahbbūb), biskup Manbidż (dzisiejsza Syria), żyjący na przełomie XI i X w. ${ }^{96}$

W sposób oczywisty słabością tego wyjaśnienia jest fakt, że wszelkie świadectwa dotyczące relacji między Danem i Judaszem są późniejsze niż NT ${ }^{97}$. Bezsprzecznie jednak związek między dwunastoma plemionami i dwunastoma apostołami obecny na kartach NT uwiarygodnia takie rozwiązanie.

\section{Wnioski}

Opieczętowani, w symbolicznej liczbie 144 000, to odnowiony Izrael-Kościół. Jest to zjednoczony lud ST, reprezentowany przez dwanaście plemion, oraz NT, reprezentowany przez dwunastu apostołów, oddający hołd Mesjaszowi-Barankowi. Członkami Izraela są zarówno poganie, jak i etniczni Żydzi. Nie jest to jakaś ograniczona grupa będąca częścią Izraela, ale cały Izrael.

Lista dwunastu plemion nie ma swego dokładnego odpowiednika w ST ani też w pozabiblijnej literaturze żydowskiej. Najprawdopodobniej bazuje ona na

Tomasza 30-33 (wąż który nakłonił Judasza do wydania Jezusa), Arabska Ewangelia Dziecięctwa 42, Tomaszowa Ewangelia Dziecięctwa 16 (grecki tekst), 15 (łaciński tekst) czy też Ewangelia Pseudo-Mateusza 41. Powiązanie między wężem, Danem i Judaszem jest o tyle istotne w kontekście Ap, że księga ta nasycona jest polemiką z Szatanem przedstawianym

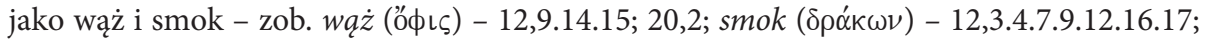
$13,2.4 .11 ; 16,13 ; 20,2$. Wąż ten, co istotne, identyfikowany jest $\mathrm{z}$ wężem z Rdz 3,1-15 - zob. Ap 12; 20,2. Identyfikacja węża z Rdz 3 z szatanem jest widoczna w Mdr 2,24. Warto zwrócić także uwagę na teksty Filona (De agricultura 95 oraz 99), a zatem czasy współczesne powstaniu NT, który identyfikuje węża z pokolenia Dana z Rdz 49,17 z miedzianym wężem Mojżesza (Lb 21,4-9) i explicite przeciwstawia się jego powiązaniu z wężem protoewangelii (Rdz 3,1-15). Winkle (Another Look, 61, przypis 22) zwraca uwagę na T. Dan 1,4-7, wg którego Danowi podobało się sprzedanie Józefa do niewoli oraz Dan ucieszył się śmiercią Józefa. Winkle sugeruje, że w czynach Judasza można widzieć paralelę do zachowania Dana.

96 S. Pinès, Notes, 153, przypis 14. Tekst arabski: L. Cheikho (ed.), Agapius episcopus Mabbugensis. Historia universalis (CSCO.A 10, III/5; Louvain: Peeters 1912) 242-244. Oto lista: (1) Piotr - Neftali, (2) Andrzej, (3) Jakub - Zabulon, (4) Jan, (5) Filip - Aser, (6) Bartłomiej - Issachar, (7) Tomasz - Juda, (8) Mateusz - Issachar, (9) Szymon - Efraim, (10) Juda - Symeon, (11) Jakub - Manasses, (12) Judasz Iskariota - Dan, (13) Maciej - Ruben. Brakuje w liście trzech plemion: Lewiego, Gada i Benjamina. Dwie pary braci: Piotr i Andrzej, oraz Jakub i Jan pochodzą kolejno z plemion Neftalego i Zabulona. Co ciekawe, Bartłomiej i Mateusz, którzy nie byli braćmi, pochodzą z tego samego plemienia Issachara.

97 Zob. R. Bauckham, List, 114, przypis 3. 
Rdz 49,3-27 lub Ez 48,31-34, poddana jest jednak zmianom, które mają swe źródło w ideach teologicznych autora Ap. Dla przykładu, Juda, plemię zwycięskiego Baranka, Mesjasza, stoi na czele. Daleka, ósma, pozycja Lewiego jest symbolicznym znakiem końca kapłaństwa starotestamentalnego. Przesunięcie synów niewolnic, Zilpy i Bilhy, przed pozostałych synów żon Jakubowych, Lei i Racheli, wskazuje na ustanie przywilejów wynikających z urodzenia; to znak, że członkami odnowionego Izraela są także poganie. Wysoka pozycja Manassesa może być znakiem nawrócenia Samarytan.

Obecność Manassesa w liście Janowej związana jest jednak przede wszystkim z wykluczeniem Dana spośród dwunastu plemion. Na usunięcie Danitów złożyły się dwie przyczyny. Pierwsza, to zła reputacja tego plemienia poświadczona przez ST i obecna także w czasach powstawania NT (idolatria i związek z Szatanem). Druga, to właściwe autorowi Apokalipsy, ale także innym pismom NT (Mt 19,28; Łk 22,30), spojrzenie na dwanaście plemion Izraela przez pryzmat dwunastu apostołów (Ap 21,12-14). Skutkuje ono usunięciem Dana, identyfikowanego z Judaszem, i wstawieniem na jego miejsce Manassesa. Preferencja dla Manassesa, na niekorzyść jego brata Efraima, wynika z negatywnego obrazu Efraima na kartach ST i w literaturze pozabiblijnej okresu NT, jako idolatry i rebelianta. Brak Dana i Efraima, dwóch plemion powiązanych $\mathrm{z}$ bałwochwalstwem, jest znakiem czystości wiary odrodzonego Izraela.

\section{Summary}

The Old Testament and the peritestamental literature contain no list of the sons of Jacob-Israel or of the tribes of Israel which corresponds exactly to the list in Rev 7:5-8, with regard to either order or content. Neither genealogical nor geographical principles apply to the list. If, however, one sees in this list a portrayal of the Church as the restored, eschatological Israel, built out of the twelve tribes on the foundation of the twelve apostles, then both the choice of the names and their order conform to reasonable explanation. The most salient issue, namely the dropping of Dan from the list, is most likely the result of this tribe's association with idolatry and with Judas Iscariot. Similarly, the mention of Manasseh instead of, as one might expect, his younger but more privileged brother Ephraim, likely stems from the association of the latter with idolatry and rebellion. 